\title{
Reactive oxygen species and transcript analysis upon excess light treatment in wild-type Arabidopsis thaliana vs a photosensitive mutant lacking zeaxanthin and lutein
}

Alessandro Alboresi ${ }^{1 \dagger}$, Luca Dall'Osto $^{1 \dagger}$, Alessio Aprile ${ }^{2}$, Petronia Carillo ${ }^{3}$, Enrica Roncaglia ${ }^{4}$, Luigi Cattivelli ${ }^{2}$ and Roberto Bassi ${ }^{\text {* }}$

\begin{abstract}
Background: Reactive oxygen species (ROS) are unavoidable by-products of oxygenic photosynthesis, causing progressive oxidative damage and ultimately cell death. Despite their destructive activity they are also signalling molecules, priming the acclimatory response to stress stimuli.

Results: To investigate this role further, we exposed wild type Arabidopsis thaliana plants and the double mutant npq1/ut2 to excess light. The mutant does not produce the xanthophylls lutein and zeaxanthin, whose key roles include ROS scavenging and prevention of ROS synthesis. Biochemical analysis revealed that singlet oxygen $\left({ }^{1} \mathrm{O}_{2}\right)$ accumulated to higher levels in the mutant while other ROS were unaffected, allowing to define the transcriptomic signature of the acclimatory response mediated by ${ }^{1} \mathrm{O}_{2}$ which is enhanced by the lack of these xanthophylls species. The group of genes differentially regulated in npq1/ut2 is enriched in sequences encoding chloroplast proteins involved in cell protection against the damaging effect of ROS. Among the early fine-tuned components, are proteins involved in tetrapyrrole biosynthesis, chlorophyll catabolism, protein import, folding and turnover, synthesis and membrane insertion of photosynthetic subunits. Up to now, the flu mutant was the only biological system adopted to define the regulation of gene expression by ${ }^{1} \mathrm{O}_{2}$. In this work, we propose the use of mutants accumulating ${ }^{1} \mathrm{O}_{2}$ by mechanisms different from those activated in flu to better identify ROS signalling.

Conclusions: We propose that the lack of zeaxanthin and lutein leads to ${ }^{1} \mathrm{O}_{2}$ accumulation and this represents a signalling pathway in the early stages of stress acclimation, beside the response to ADP/ATP ratio and to the redox state of both plastoquinone pool. Chloroplasts respond to ${ }^{1} \mathrm{O}_{2}$ accumulation by undergoing a significant change in composition and function towards a fast acclimatory response. The physiological implications of this signalling specificity are discussed.
\end{abstract}

\section{Background}

Plant growth is inhibited by many forms of abiotic stress, including intense light [1], nitrogen and phosphorus starvation $[2,3]$, water stress/high salinity [4] and extreme temperatures [5,6]. Excess light induces the reorganization of the photosynthetic apparatus to facilitate light harvesting while avoiding potentially damaging

\footnotetext{
* Correspondence: roberto.bassi@univr.it

† Contributed equally

${ }^{1}$ Dipartimento di Biotecnologie, Università di Verona, Strada Le Grazie 15,

I - 37134 Verona, Italy

Full list of author information is available at the end of the article
}

effects. Concomitantly, metabolism is redirected towards the synthesis of protective compounds such as flavonoids $[7,8]$, tocopherol and carotenoids $[9,10]$, which participate directly in stress responses.

The chloroplast is a crucial intersection for environmental stimuli [11-13]. Short-term responses to excess light, elicited in a timeframe of seconds to minutes, include enhanced thermal dissipation of light energy [14-16] and detachment of the outer antenna system from the photosystem II (PSII) reaction centre $[17,18]$. Longer-term acclimation responses include an increase in the PSI/PSII ratio, and the production of Rubisco,

\section{Biomed Central}


cytochrome $b_{6} / f$ complexes and ATPase at higher levels in order to increase the rate of $\mathrm{O}_{2}$ evolution under saturating light conditions and avoid plastoquinone (PQ) over-reduction. Moreover, the capacity for thermal energy dissipation (Non-Photochemical Quenching, NPQ) increases as PsbS accumulates [19,20].

Although cytochrome $b_{6} / f$, ATPase and Rubisco are encoded by chloroplast genes, the vast majority of plastid polypeptides are encoded by nuclear genes and are imported as precursors through the plastid envelope $[21,22]$. Acclimatory responses therefore require the coordinated regulation of plastid and nuclear genes, which involves a retrograde signal [12,23-27]. In the last decade transcriptome analysis has confirmed the importance and sophistication of this regulatory network $[13,28-30]$, but the signals and transduction pathways are not yet fully understood. Proposed signalling molecules include Mg-protoporphyrin IX [31], which couples the rate of chlorophyll synthesis to the expression of nuclear-encoded pigment-binding proteins, and the redox equilibrium of plastoquinone $\left(\mathrm{PQ} / \mathrm{PQH}_{2}\right)$ [32]. However, Mg-protoporphyrin IX is absent under conditions leading to the repression of nuclear genes [33], and only 54 nuclear genes appear to be controlled by the PQ redox state and photosynthetic electron flow (PEF) [34], casting doubt on their proposed role. Furthermore, analysis of the barley viridis zb63 mutant (which has a constitutively reduced PQ pool) suggests that the expression of photosynthesis-related genes is not coupled to the redox state of PQ [35].

Reactive oxygen species (ROS) have recently been proposed as candidate signalling molecules in acclimation because they can modulate gene expression when added to cell culture media, and gene expression patterns are altered in mutants accumulating higher or lower levels of ROS [36-38]. Although renowned for the damage they cause to proteins, lipids and nucleic acids [39], ROS also have several important physiological functions such as defence against pathogens [40] and the regulation of plant development [41-43]. Plants have evolved a complex regulatory network to mediate abiotic stress responses based on ROS synthesis, scavenging and signalling, although more work is needed to decipher the signalling pathways and the crosstalk between them $[36,44,45]$. Signals representing environmental changes are the first important step leading to plant acclimation and survival [37].

We exposed Arabidopsis thaliana plants to intense light at low temperatures, which strongly inhibits photosynthetic electron flow and reduces PSII efficiency, leading to the over-excitation of pigments and the accumulation of singlet oxygen $\left({ }^{1} \mathrm{O}_{2}\right)$, a peculiar ROS species that is the first excited electronic state of molecular oxygen [46]. We compared wild-type plants to the double mutant npq1lut2, which lacks violaxanthin deepoxidase (VDE) and lycopene- $\varepsilon$-cyclase (LUT2) activities, and therefore cannot synthesize two major photoprotective xanthophylls: lutein and zeaxanthin. These molecules help to quench chlorophyll triplet states $\left({ }^{3} \mathrm{Chl}^{*}\right)$ and scavenge ${ }^{1} \mathrm{O}_{2}$ released within the thylakoid membrane $[47,48]$. Due to the defect in xanthophyll composition, the npq1lut2 mutant exhibits a remarkable sensitivity to high light [49] and accumulates higher levels of ${ }^{1} \mathrm{O}_{2}$ than wild-type plants, while the accumulation of other ROS is unaffected as are other putative retrograde signals such as the PQ redox state and the ATP/ADP ratio. The system that gave a great breakthrough in the study of ${ }^{1} \mathrm{O}_{2}$ accumulation in plants is the conditional flu mutant. This mutant in the dark accumulates protochlorophyllide that acts as a photosensitizer upon illumination and generates ${ }^{1} \mathrm{O}_{2}$ in the stroma of chloroplasts [50]. In $f l u,{ }^{1} \mathrm{O}_{2}$ accumulation mediates the activation of a stress response [29] that is different from those induced by other ROS such as superoxide anion $\left(\mathrm{O}_{2}{ }^{-}\right)$or hydrogen peroxide $\left(\mathrm{H}_{2} \mathrm{O}_{2}\right)$ [30]. Further results showed that Executer1/2 are chloroplast proteins crucial for ${ }^{1} \mathrm{O}_{2}$-mediated stress responses [51]. However, xanthophyll mutants have been recently used to study the effect and the signalling pathway of ${ }^{1} \mathrm{O}_{2}[46,52]$. We are clearly dealing with two different systems that accumulate ${ }^{1} \mathrm{O}_{2}$. The most studied that depends on ${ }^{1} \mathrm{O}_{2}$ steady-state accumulation from chlorophyll precursors and the second one that depends on the photoprotective activity of xanthophylls in thylakoid membranes. In the first case the toxic effect of ${ }^{1} \mathrm{O}_{2}$ has a major role in defining the phenotype, while in npq1lut2 its effect as signal molecule is more important. We applied stress conditions within a physiological range, leading to acclimation rather than the apoptotic responses reported in previous studies [30,53]. By limiting cross-talk between the apoptotic and acclimatory signal transduction pathways, we found that ${ }^{1} \mathrm{O}_{2}$ can function as a signal in both wild-type and npq1lut2 mutants under oxidative stress.

\section{Results}

Genes regulated by intense light at low temperatures in wild-type and mutant plants

An Affymetrix GeneChip ${ }^{\circledR}$ Arabidopsis ATH1 Genome Array was used to compare the transcriptional footprints of wild-type Arabidopsis thaliana plants and the npq1lut2 mutant when both were transferred at $10^{\circ} \mathrm{C}$ and exposed to either very low light levels (time 0 , before the application of stress) or very high light levels $\left(1000 \mu \mathrm{mol} \mathrm{m} \mathrm{m}^{-2} \mathrm{~s}^{-1}\right)$ for 2 or $24 \mathrm{~h}$ (Figure 1). Three biological replicates were analyzed in each treatment group. These conditions (low temperature associated to high light) were carefully chosen in order to emphasize the 


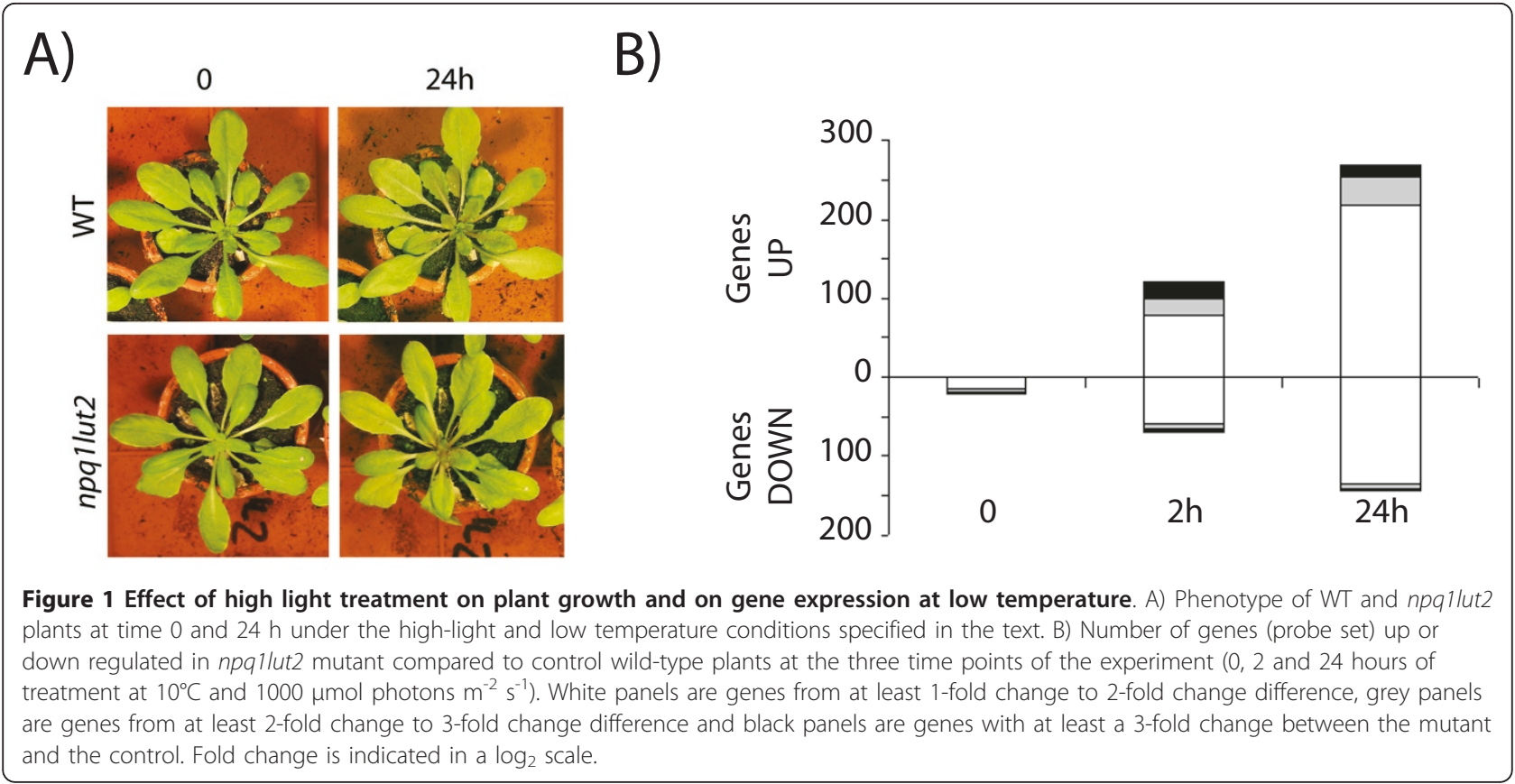

effect caused by the lack of the two photoprotective xanthophylls [47].

We noted that many genes were similarly regulated by light at low temperatures regardless of the genetic background, i.e. they were not influenced by the mutations. We have first compared different time points for each genotype to identify genes responding in the same way in both genotypes. These genes represent the response to high-light and low-temperature conditions in our experiment. Among the rapidly-responding genes (reaction to stress within $2 \mathrm{~h}$ ), 812 were modulated in both wild-type and mutant plants, all showing the same directional response in both backgrounds (476 up-regulated and 336 down-regulated; Additional file 1: Table S1). Among the delayed-response genes (reaction to stress within $24 \mathrm{~h}$ ), 1128 genes were modulated in both backgrounds, again all showing the same directional response (611 up-regulated and 517 down-regulated; Additional file 1: Table S2).

Functional classification of the above genes was carried out using FunCat version 2.1 [54] and the most significant results $(\mathrm{p}<0.005)$ are summarized in Table 1 . A complete list with subcategories is provided in Additional file 1: Table S3. Many of the genes (up-regulated and down-regulated) fell into the Cell Rescue, Interaction with Cell Environment and Interaction with the Environment categories, which are generally associated with stress responses or hormone signalling. Among the down-regulated genes, there was a significant overrepresentation of those in the Control of Transcription and Cell Wall Biogenesis functional categories, whereas many genes involved in Primary and Secondary Metabolism were up-regulated (176 after 2 h, 210 after 24 h). For example, a change in L-phenylalanine metabolism, reflecting the overexpression of chloroplast chorismate mutase (AT3G29200; CM1) and phenylalanine ammonia-lyase 1 (AT2G37040; PAL1), could serve as a secondary pathway for the synthesis of phenylpropanoids and flavonoids. Additional file 1: Table S3 shows that photosynthesis, energy conversion and regeneration, and light absorption are down-regulated after $24 \mathrm{~h}$, possibly because energy pathways are overloaded and therefore feedback-inhibited when constantly exposed to intense light.

The ten most strongly modulated genes after $2 \mathrm{~h}$ included several with a regulatory function, which are likely to be involved in the activation of a stress response according to their GENEVESTIGATOR response profiles (Additional file 1: Table S1). These comprised three transcription factors (AT4G28140, AT1G56650 and AT2G20880), two heat shock proteins (AT3G12580 and AT2G20560) and one putative allene oxide cyclase (AT3G25780). After $24 \mathrm{~h}$ we observed the strong induction of genes known or suspected to be involved in flavonoid biosynthesis or modification, i.e. dihydroflavonol 4-reductase, DFR, AT5G42800; anthocyanin 5-aromatic acyltransferase, AAT1, AT1G03940AT1G03495; anthocyanin pigment 2 protein, $P A P 2$, AT1G66390; anthocyanin 5-O-glucosyltransferase, AT4G14090; flavonoid 3'-hydroxylase, F3' $H$, AT5G07990; MYB family transcription factor, MYB75/ PAP1, AT1G56650; UDP-glucosyl transferase, 
Table 1 Functional classification of genes regulated by intense light at $10^{\circ} \mathrm{C}$

\begin{tabular}{|c|c|c|c|c|}
\hline Functional Categories & UP 2 h (476) & UP 24 h (606) & DOWN 2 h (336) & DOWN 24 h (370) \\
\hline 01 Metabolism & $19.6(176)$ & $17.3(210)$ & - & - \\
\hline 02 Energy & - & $2.2(23)$ & - & - \\
\hline 11 Transcription & - & - & $7.5(57)$ & $4.5(72)$ \\
\hline 14 Protein Fate & $5.4(78)$ & - & - & - \\
\hline 16 Binding Function & $7.0(151)$ & $5.3(182)$ & - & - \\
\hline 20 Transport & $3.8(59)$ & - & - & - \\
\hline 30 Signal Transduction & - & - & - & $2.9(38)$ \\
\hline 32 Cell Rescue & $14.1(91)$ & $7.99(79)$ & - & $4.1(47)$ \\
\hline 34 Interaction with Cell Environment & $12.4(87)$ & $6.89(77)$ & $7.2(44)$ & $9.5(79)$ \\
\hline 36 Interaction with the Environment & $7.2(47)$ & - & $3.9(22)$ & $6.3(43)$ \\
\hline 40 Cell Fate & - & - & - & $3.7(27)$ \\
\hline 70 Subcellular Localization & - & 16.7 (326) & $10.6(160)$ & - \\
\hline
\end{tabular}

Function and cellular localization of genes regulated by intense light $\left(1000 \mu \mathrm{mol}\right.$ photon $\left.\mathrm{m}^{-2} \mathrm{~s}^{-1}, 10^{\circ} \mathrm{C}\right)$ in both wild-type and $n p q 1 /$ ut 2 mutant plants. Functional categories and their consistency were defined using MIPS functional catalogue ( $\leq 0.005)$. Up-regulated and down-regulated genes were analyzed after 2 and $24 \mathrm{~h}$ stress. For each subset, the number of genes is shown in brackets.

AT5G54060; and anthocyanidin synthase, AT4G22870 (Additional file 1: Table S2). These genes are known to be important checkpoints in flavonoid biosynthesis as shown by microarray experiments performed under various abiotic stress conditions [7].

\section{Genes regulated by intense light at low temperatures in mutant plants only}

Only 20 genes were found to be differentially expressed when unstressed wild type and mutant plants were compared (18, considering that two of them are responsible for npq1lut2 mutation). All 18 genes were down-regulated in the mutant, suggesting that the two backgrounds are metabolically very similar when there is no stress and that the 18 genes may be directly influenced by the lack of NPQ1 and LUT2 enzyme activities, or of the corresponding products (Figure 1).

Following exposure to intense light, the number of differentially expressed genes increased dramatically. After $2 \mathrm{~h}, 121$ genes were up-regulated in the mutant and 69 down-regulated, and after 24 h, 270 genes were up-regulated and 144 down-regulated (Figure 1). The distribution of functional categories among these genes was similar to the genes modulated in the same manner in both backgrounds. However, a distinct group of 67 genes specifically repressed in the wild type plants after $2 \mathrm{~h}$ of stress but not repressed in the mutant $(\mathrm{p}=1.12$ $\times 10^{-9}$ ) was shown to encode chloroplast proteins (Table 2), 38 with no known function and others identified as transcription factors and pentatricopeptide repeat-containing proteins (PPR), possibly participating in ROS signal transduction from the chloroplast to the nucleus and vice versa [55]. This indicates that nuclear gene expression might be influenced by carotenoid composition and anti-oxidant activity in thylakoid membranes, especially when plants are placed under oxidative stress.
Focusing on differences in expression levels (Additional file 1: Table S4), we noticed that genes encoding heat-shock proteins (AT3G12580, AT5G51440 and AT1G59860-AT1G07400) were more strongly up-regulated in the mutant after $24 \mathrm{~h}$, as were those encoding antioxidant proteins such as 2-alkenal reductase ( $A E R$; AT5G16970), which catalyzes the reduction of the $\alpha, \beta$ unsatured bond of reactive carbonyls [56], methionine sulfoxide reductase 3 (MSR3; AT5G61640), which promotes thioredoxin-dependent reduction of oxidized methionine residues in ROS-damaged proteins [57], and the oxidative stress protein rubredoxin (AT5G51010) [58]. A squalene monooxygenase 1,1 gene (SQP1,1; AT5G24150) is $12 \mathrm{x}$ more strongly repressed in wild type plants than in mutants and might be the base for changes in plant morphology or oxidative stress response in HL conditions $[59,60]$.

\section{Gene clustering}

We next carried out a k-means cluster analysis, which organized all modulated genes into 11 clusters that differed little between wild-type and npq1lut2 (Additional file 2: Figure S1A). Therefore, an implemented cluster analysis was performed using a quality threshold algorithm (QT-clustering), in which we only considered genes with differences in transcript levels between the two genotypes at the three time points, i.e. 20 genes for time 0,190 genes for time $2 \mathrm{~h}$ and 414 genes for time $24 \mathrm{~h}$ (Figure 1). The minimum number of probe-sets per cluster was fixed at 10, with a Pearson's correlation value fixed at 0.75 . The number of clusters increased to 18, plus a group of 161 unclassified genes (Additional file 2: Figure 1B). Once again, there were few differences between the genotypes, with the exception of e.g. clusters $1,3,13$ and 18. Cluster 18 attracted our attention because it showed the most striking difference between 
Table 2 Expression of genes down-regulated in response to intense light at low temperature exclusively in wild-type plants ( $2 \mathrm{~h}$ time point)

\begin{tabular}{|c|c|c|c|}
\hline Probeset & Locus identifier & Description & WT Ovs2 \\
\hline 265067_at & AT1G03850 & glutaredoxin family protein & $-2,83$ \\
\hline 264379_at & AT2G25200 & expressed protein & $-2,67$ \\
\hline 248606_at & AT5G49450 & bZIP family transcription factor & $-2,04$ \\
\hline 249932_at & AT5G22390 & expressed protein & $-1,96$ \\
\hline 253305_at & AT4G33666 & expressed protein & $-1,74$ \\
\hline 263674_at & AT2G04790 & expressed protein & $-1,62$ \\
\hline 261196_at & AT1G12860 & basic helix-loop-helix (bHLH) family & $-1,51$ \\
\hline 256698_at & AT3G20680 & expressed protein & $-1,48$ \\
\hline 263209_at & AT1G10522 & expressed protein & $-1,48$ \\
\hline 248285_at & AT5G52960 & expressed protein & $-1,37$ \\
\hline 249750_at & AT5G24570 & expressed protein & $-1,35$ \\
\hline 247574_at & AT5G61230 & ankyrin repeat family protein & $-1,34$ \\
\hline 266899_at & AT2G34620 & mitochondrial transcription factor-related & $-1,34$ \\
\hline 261118_at & AT1G75460 & ATP-dependent protease La (LON) & $-1,31$ \\
\hline 263712_at & AT2G20585 & expressed protein & $-1,27$ \\
\hline 248795_at & AT5G47390 & myb family transcription factor & $-1,27$ \\
\hline 263593_at & AT2G01860 & pentatricopeptide (PPR) repeat-containing & $-1,26$ \\
\hline 254688_at & AT4G13830 & DNAJ heat shock N-terminal (J20) & $-1,24$ \\
\hline 261296_at & AT1G48460 & expressed protein & $-1,24$ \\
\hline 257615_at & AT3G26510 & octicosapeptide/Phox/Bem1p (PB1) & $-1,24$ \\
\hline 265457_at & AT2G46550 & expressed protein & $-1,23$ \\
\hline 249472_at & AT5G39210 & expressed protein & $-1,23$ \\
\hline 252136_at & AT3G50770 & calmodulin-related protein & $-1,21$ \\
\hline 252922_at & AT4G39040 & expressed protein & $-1,20$ \\
\hline 267591_at & AT2G39705 & expressed protein & $-1,20$ \\
\hline 257856_at & AT3G12930 & expressed protein & $-1,20$ \\
\hline 263264_at & AT2G38810 & histone $\mathrm{H} 2 \mathrm{~A}$ & $-1,19$ \\
\hline 249929_at & AT5G22340 & expressed protein & $-1,18$ \\
\hline 266329_at & AT2G01590 & expressed protein & $-1,18$ \\
\hline 248762_at & AT5G47455 & expressed protein & $-1,17$ \\
\hline 246506_at & AT5G16110 & expressed protein & $-1,17$ \\
\hline 258250_at & AT3G15850 & similar to delta 9 acyl-lipid desaturase (ADS1) & $-1,15$ \\
\hline 258683_at & AT3G08760 & protein kinase family & $-1,15$ \\
\hline 259013_at & AT3G07430 & YGGT family protein & $-1,14$ \\
\hline 253635_at & AT4G30620 & expressed protein & $-1,14$ \\
\hline 246033_at & AT5G08280 & hydroxymethylbilane synthase & $-1,14$ \\
\hline 248404_at & AT5G51460 & trehalose-6-phosphate phosphatase (TPPA) & $-1,13$ \\
\hline 248402_at & AT5G52100 & dihydrodipicolinate reductase family protein & $-1,13$ \\
\hline 256728_at & AT3G25660 & glutamyl-tRNA(Gln) amidotransferase & $-1,12$ \\
\hline 248663_at & AT5G48590 & expressed protein & $-1,12$ \\
\hline 245984_at & AT5G13090 & expressed protein & $-1,12$ \\
\hline 250663_at & AT5G07110 & prenylated rab acceptor (PRA1) & $-1,11$ \\
\hline 254011_at & AT4G26370 & antitermination NusB domain & $-1,10$ \\
\hline 261439_at & AT1G28395 & expressed protein & $-1,10$ \\
\hline 259889_at & AT1G76405 & expressed protein & $-1,10$ \\
\hline 253233_at & AT4G34290 & SWIB complex BAF60b domain & $-1,10$ \\
\hline 259976_at & AT1G76560 & CP12 domain-containing & $-1,10$ \\
\hline 260465_at & AT1G10910 & pentatricopeptide (PPR) repeat & $-1,10$ \\
\hline 246205_at & AT4G36970 & remorin family protein & $-1,09$ \\
\hline 257706_at & AT3G12685 & expressed protein & $-1,09$ \\
\hline
\end{tabular}


Table 2 Expression of genes down-regulated in response to intense light at low temperature exclusively in wild-type plants ( 2 h time point) (Continued)

\begin{tabular}{|c|c|c|c|}
\hline 267219_at & AT2G02590 & expressed protein & $-1,08$ \\
\hline 264546_at & AT1G55805 & BolA-like family protein & $-1,08$ \\
\hline 258189_at & AT3G17860 & expressed protein & $-1,08$ \\
\hline 245877_at & AT1G26220 & GCN5-related N-acetyltransferase (GNAT) & $-1,06$ \\
\hline 266889_at & AT2G44640 & expressed protein & $-1,05$ \\
\hline 264963_at & AT1G60600 & Phyllo- and plastoquinone biosynthesis & $-1,05$ \\
\hline 260982_at & AT1G53520 & chalcone-flavanone isomerase-related & $-1,04$ \\
\hline 250529_at & AT5G08610 & DEAD box RNA helicase $(\mathrm{RH} 26)$ & $-1,04$ \\
\hline 246294_at & AT3G56910 & expressed protein & $-1,04$ \\
\hline 249694_at & AT5G35790 & Plastidic glucose-6-phosphate dehydrogenase & $-1,03$ \\
\hline 266264_at & AT2G27775 & expressed protein & $-1,02$ \\
\hline 245494_at & AT4G16390 & chloroplastic RNA-binding protein P67 & $-1,02$ \\
\hline 250353_at & AT5G11630 & expressed protein & $-1,02$ \\
\hline 248688_at & AT5G48220 & Indole-3-glycerol phosphate synthase & $-1,01$ \\
\hline 259738_at & AT1G64355 & expressed protein & $-1,00$ \\
\hline 250097_at & AT5G17280 & expressed protein & $-1,00$ \\
\hline 254755_at & AT4G13220 & expressed protein & $-0,98$ \\
\hline
\end{tabular}

The table shows the subset of genes encoding chloroplast proteins. The ratio between treated and control plants is expressed as a log ${ }_{2}$ scale. For each sample, the average of three repetitions is presented.

wild-type and npq1lut2 plants, and is strongly enriched in chloroplast genes (Table 3). Indeed, among the 80 probes in the Arabidopsis ATH1 Genome Array representing genes in the chloroplast genome (ATC codes), five belong to cluster 18. One of these genes encodes a protein hypothetically involved in PSI assembly (AtYCF4, ATCG00520), two encode photosystem core complex proteins, PsbB from PSII (D2; ATCG00270) and PsaA from PSI (ATCG00350), and two encode ATPase subunits (ATCG00130 and ATCG00140). Other genes in cluster 18 encode a transcription factor regulating the cryptochrome response (AtCIB5, AT1G26260), an L-ascorbate oxidase (AT4G39830), a kinase (AT1G21270) and two unknown proteins (AT1G23850 and AT2G46640). All these genes are modulated by intense light at low temperature in the wild-type, while there is no response in the mutant.

\section{ROS analysis in wild-type and npq1lut2 leaves}

The npq1lut2 mutant was chosen because of its high sensitivity to photooxidative stress $[47,49]$. We determined the composition of ROS species released after the onset of illumination by infiltrating wild-type and mutant leaves with highly specific ROS-sensor probes: singlet-oxygen sensor green (SOSG) for ${ }^{1} \mathrm{O}_{2}$, dichlorofluorescein (DCF) for $\mathrm{H}_{2} \mathrm{O}_{2}$ and $\mathrm{OH}$., and proxyl-fluorescammine (ProxF) for $\mathrm{O}_{2}{ }^{-}$and OH.[61]. All these probes show an increase in fluorescence emission in the presence of their specific trigger ROS, and the signal can be detected directly on the surface of an illuminated leaf using a fiber-optic fluorimeter. In particular, among all available probes specific for ${ }^{1} \mathrm{O}_{2}$, we chose SOSG because, unlike other available fluorescent and chemiluminescent ${ }^{1} \mathrm{O}_{2}$ detection reagents, it does not show any appreciable response to hydroxyl radical, $\mathrm{H}_{2} \mathrm{O}_{2}$ or superoxide anion; moreover, it was successfully applied to ${ }^{1} \mathrm{O}_{2}$ detection in several systems, e.g. bacteria [62], diatoms [63], higher plants $[48,63,64]$ and pigment-protein complexes isolated from higher plants $[17,65]$. Furthermore, C. Flors and co-workers applied SOSG to a range of biological systems that are known to generate ${ }^{1} \mathrm{O}_{2}$ and in all cases, SOSG was confirmed as a useful in vivo probe for the detection of ${ }^{1} \mathrm{O}_{2}$. Moreover, since highly sensitive probes for detection of $\mathrm{H}_{2} \mathrm{O}_{2}, \mathrm{O}_{2}{ }^{-}$and $\mathrm{OH}$. were also used in all measurements, any cross-detection

Table 3 Relevant cluster isolated by QT clustering

\begin{tabular}{llll}
\hline & $\begin{array}{l}\text { Locus } \\
\text { identifier }\end{array}$ & FC & Description \\
\hline 245002_at & ATCG00270 & $-1,53$ & Encode PSII D2 \\
245007_at & ATCG00350 & $-2,22$ & Encode PSI psaApsaB \\
245018_at & ATCG00520 & $-1,20$ & Hypothetical protein \\
245025_at & ATCG00130 & $-1,41$ & ATPase F subunit \\
245026_at & ATCG00140 & $-1,30$ & ATPase III subunit \\
245873_at & AT1G26260 & $-1,05$ & CIB5, bHLH \\
252862_at & AT4G39830 & $-2,50$ & L-ascorbate oxidase putative \\
259560_at AT1G21270 & $-1,04$ & serine/threonine protein kinase 2 \\
& & & (WAK2) \\
263032_at & AT1G23850 & $-3,03$ & expressed protein \\
266320_at & AT2G46640 & $-1,01$ & expressed protein \\
\hline
\end{tabular}

This table shows the subset of genes in cluster 18 . The ratio between npq1/ut2 and wild-type plants after $2 \mathrm{~h}$ stress is expressed using a $\log _{2}$ scale. For each sample, the average of three repetitions is presented. 
of other ROS species than ${ }^{1} \mathrm{O}_{2}$ by SOSG can be excluded.

The results in Figure 2 show that only SOSG fluorescence differed according to the genotype, with significantly higher fluorescence in mutant leaves (Figure 2C); there was no significant difference in the DCF and ProxF signals (Figures 2A, B). These results show that the accumulation of ${ }^{1} \mathrm{O}_{2}$ is selectively enhanced in npq1lut2 mutant leaves whereas the other ROS are accumulated at the same level in both the mutant and wild-type. These data were confirmed by determining the extent of protein oxidation in thylakoids using the Millipore OxyBlot kit: npq1lut2 plants showed evidence of increased protein carbonylation after 1 day exposure to excess light, whereas wild-type plants took 5 days before an increase was detectable and the amplitude of the signal was far lower (Figure 2D).

It has been reported that the chloroplast can control the rate of transcription in the nucleus via the redox state of PQ [32], the ADP/ATP ratio and the redox state of stromal components $[66,67]$. In order to determine whether differences in gene expression between wild-type and mutant plants reflected differences in ${ }^{1} \mathrm{O}_{2}$ steady-state accumulation, we studied the kinetics of these parameters under the same stress conditions described above. There were no major differences in $\mathrm{qP}$, ascorbate and glutathione redox state, and ADP/ATP ratio, but there was a significantly greater reduction in maximum PSII photochemical efficiency $(\mathrm{Fv} / \mathrm{Fm})$ in mutant within the first $2 \mathrm{~d}$, which reflects PSII damage induced by high ${ }^{1} \mathrm{O}_{2}$ levels (Table 4).

Nevertheless, acclimation to stress conditions led to the recovery of $\mathrm{Fv} / \mathrm{Fm}$ in both wild-type and npq1lut 2 plants within 3 days (Table 4). The levels of ascorbate and glutathione increased in both genotypes upon HL treatment. Ascorbate accumulates at even higher extent in wild-type leaves than npq1lut2 in response to HL. On the contrary, the total amount of ATP and ADP was only slightly affected by stress treatment in both genotypes (Additional file 2: Figure S3).

\section{Regulation of photosynthetic pigment metabolism}

We next investigated the transcriptional regulation of genes in the chlorophyll and carotenoid metabolic pathways, since these pigments play an important role in light harvesting and photoprotection, and pigment-protein complexes are the main sources of ${ }^{1} \mathrm{O}_{2}$ in thylakoids when the photosynthetic machinery is overexcited $[46,68]$. Specifically, we studied the carotenogenic genes (Additional file 1: Table S5) and the Lhc (Figure 3) and $P s a / P s b$ gene families (Table 5) to see if their expression was sensitive to HL treatment.

We identified several genes in the chlorophyll biosynthetic pathway that were differentially regulated in wild- type and mutant plants exposed to excess light at low temperature. We found that heme oxygenase 3 (AT1G69720), which catalyzes the rate-limiting step in the degradation of heme, uroporphyrin III C-methyltransferase (AT5G40850), which is involved in siroheme biosynthesis, and glutamate-1-semialdehyde 2,1-aminomutase (AT3G48730) and uroporphyrinogen III synthase (AT2G26540), which catalyze steps in porphyrin and chlorophyll metabolism, were induced much more strongly in the mutant. In contrast, for a gene encoding protochlorophyllide reductase B (AT4G27440), which is involved in the light-dependent step of chlorophyllide $a$ biosynthesis, was repressed specifically in the mutant (Additional file 1: Table S5). These results indicate that HL-treatment on npq1lut2 plants redirects the porphyrin biosynthetic pathway from chlorophyll synthesis to the production of heme and siroheme, thus reducing the total amount of chlorophyll in the overexcited system. Consistently, the chlorophyll content per leaf area decreased more rapidly in mutant plants than wild type plants exposed to excess light (Figure 4C).

Several genes in the xanthophyll biosynthesis pathway were up-regulated in both wild-type and mutant plants, with stronger induction after $24 \mathrm{~h}$. These included phytoene synthase (AT5G17230), phytoene dehydrogenase (AT4G14210, AT1G57770), lycopene- $\beta$-cyclase (AT3G10230), $\beta$-carotene hydroxylase chy1 (AT4G25700) and zeaxanthin epoxidase (AT5G67030). The strong up-regulation of carotenogenic genes in response to elevated irradiation would sustain chloroplast acclimation. The carotenoid content of whole leaves supported this hypothesis, since mutant plants acclimated to a lower $\mathrm{Chl} / \mathrm{Car}$ ratio than wild-type plants after $6 \mathrm{~d}$ exposed to excess light at low temperature (Figure 4B), suggesting that ${ }^{1} \mathrm{O}_{2}$ signalling can account for the modulation of xanthophyll content in the thylakoid membrane. The differential expression of $V T E 1$ in wild-type and mutant plants (Additional file 1: Table S6) is consistent with the higher tocopherol production in the mutant plants exposed to stress conditions (Figure 4D).

\section{Regulation of pigment-binding proteins}

Lhc proteins are located within the thylakoid membranes, where they coordinate the chlorophylls and carotenoids. They are encoded by a superfamily of nuclear genes whose transcription [69], translation [70-72] and protein accumulation $[20,35]$ are finely regulated in response to environmental cues. The expression profiles of most $L h c$ genes were very similar in wild-type and mutant plants exposed to excess light for $24 \mathrm{~h}$ (Figure 3). The genes significantly up-regulated in both genotypes were $L h c b 4.3$ (AT2G40100), Lhcb7 (AT1G76570), ELIP1 (AT3G22840) and ELIP2 (AT4G14690), indicating their involvement in 

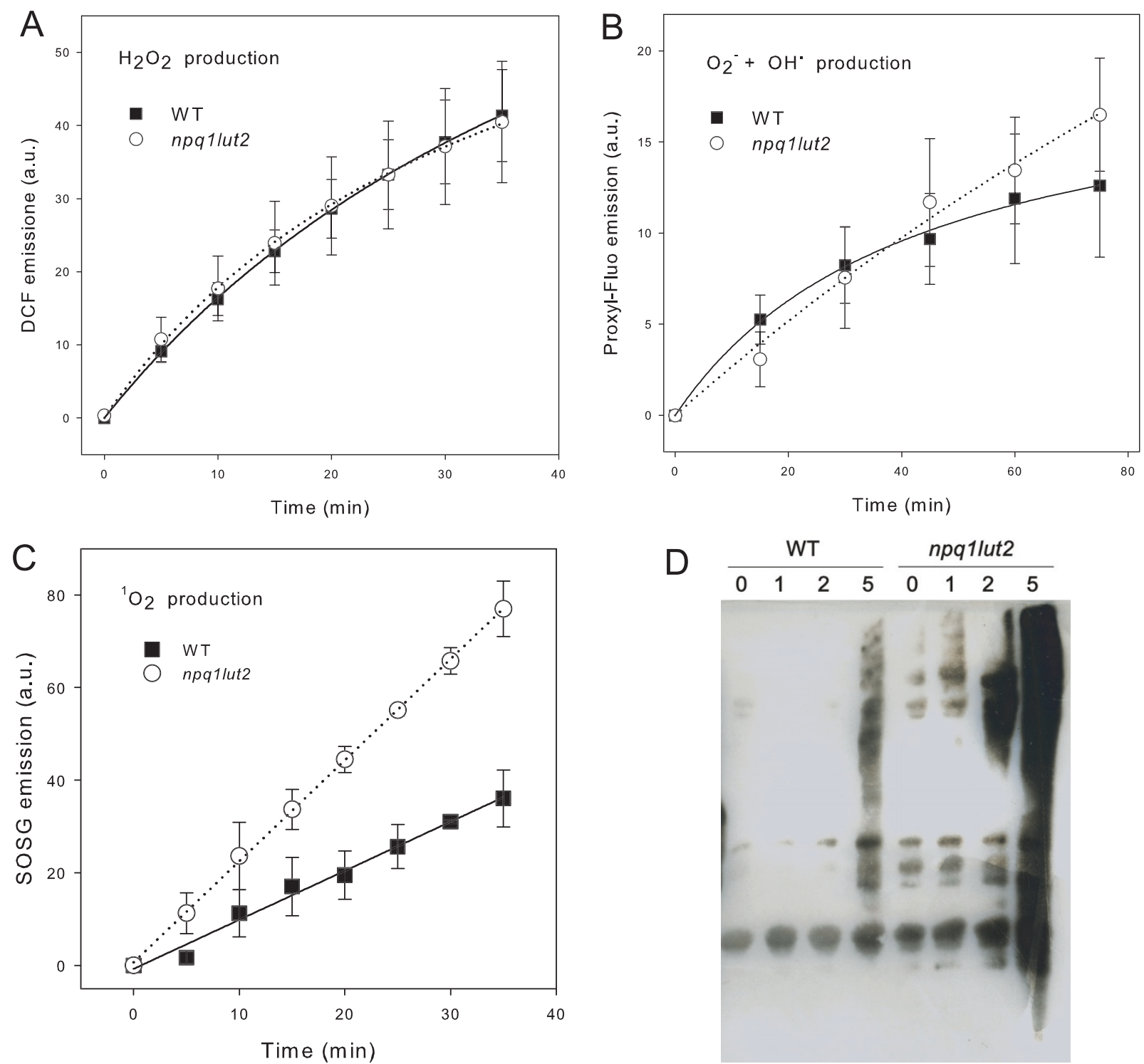

Figure 2 Steady-state accumulation of ROS species and protein oxidizing activity in wild type and npq1/ut2 mutant plants. Specific probes were used to quantify the accumulation of several ROS in wild type and npq1/ut2 detached leaves under stress (1000 $\mu$ mol photons $\mathrm{m}^{-2}$ $\mathrm{s}^{-1}, 10^{\circ} \mathrm{C}$ ). (A) DFC and (B) ProxF fluorescence was used to follow the accumulation of reduced forms of ROS. (C) SOSG fluorescence was used to follow singlet oxygen $\left({ }^{1} \mathrm{O}_{2}\right)$. Details on ROS measurements are given in material and method session. Symbols and error bars show means \pm SD. (D) Western-blots were used to detect oxidized thylakoid proteins extracted from wild type and npq1/ut2 membranes. WT and npq $1 /$ ut2 rosettes were pre-treated for $48 \mathrm{~h}$ at $10^{\circ} \mathrm{C}$ and low light as described in methods, then were exposed to photoxidative conditions $(1000 \mu \mathrm{mol}$ photon $\mathrm{m}$ ${ }^{2} \mathrm{~s}^{-1}, 10^{\circ} \mathrm{C}, 16 \mathrm{~h}$ light/8 $\mathrm{h}$ dark). Leaves were harvested and thylakoids isolated before stress (0) and at same time after 1, 2 and 5 days of HL.

the general stress response. However, Lhca4 (AT3G47470) was significantly down-regulated only in wild-type plants, whereas Lhca6 (AT1G19150) was upregulated only in the mutant.

Furthermore, many genes encoding PSII and PSI core complex subunits were significantly down-regulated in wild-type plants exposed to excess light, but up- regulated or marginally down-regulated in the mutant, i. e. CP47 (ATCG00680), D2 (ATCG00270), PsbG (ATCG00430), PsbI (ATCG00080), PsbK (ATCG00070), PsaD (AT1G03130), PsaO (AT1G08380) and PsaN (AT5G64040). Table 5 shows the gene expression ratios on the $\log _{2}$ scale. Marked fields represent probe sets showing a significant change. CP47 was more strongly 
Table 4 Time-course of main chloroplast parameters putatively involved in the regulation of gene expression, as previously reported $[32,66,67]$

\begin{tabular}{|c|c|c|c|c|c|c|c|c|c|c|c|c|}
\hline \multirow[b]{2}{*}{ Time (hours) } & \multicolumn{6}{|c|}{ WT } & \multicolumn{6}{|c|}{ npq1/ut2 } \\
\hline & 0 & 2 & 24 & 48 & 72 & 144 & 0 & 2 & 24 & 48 & 72 & 144 \\
\hline$q P$ & 1 & $\begin{array}{l}0,20 \pm \\
0,06\end{array}$ & $\begin{array}{l}0,15 \pm \\
0,07\end{array}$ & $\begin{array}{l}0,03 \pm \\
0,02\end{array}$ & $\begin{array}{l}0,05 \pm \\
0,01\end{array}$ & $\begin{array}{l}0,10 \pm \\
0,08\end{array}$ & 1 & $\begin{array}{l}0,07 \pm \\
0,03\end{array}$ & $\begin{array}{l}0,08 \pm \\
0,05\end{array}$ & $\begin{array}{l}0,02 \pm \\
0,01\end{array}$ & $\begin{array}{l}0,07 \pm \\
0,08\end{array}$ & $\begin{array}{l}0,13 \pm \\
0,08\end{array}$ \\
\hline $\mathrm{Fv} / \mathrm{Fm}$ & $\begin{array}{l}0,79 \pm \\
0,01\end{array}$ & $\begin{array}{l}0,48 \pm \\
0,07\end{array}$ & $\begin{array}{l}0,42 \pm \\
0,03\end{array}$ & $\begin{array}{l}0,47 \pm \\
0,07\end{array}$ & $\begin{array}{l}0,43 \pm \\
0,17\end{array}$ & $\begin{array}{l}0,49 \pm \\
0,07\end{array}$ & $\begin{array}{l}0,79 \pm \\
0,01\end{array}$ & $\begin{array}{l}0,51 \pm \\
0,13\end{array}$ & $\begin{array}{l}0,22 \pm \\
0,10\end{array}$ & $\begin{array}{l}0,07 \pm \\
0,03 *\end{array}$ & $\begin{array}{l}0,45 \pm \\
0,09\end{array}$ & $\begin{array}{l}0,46 \pm \\
0,13\end{array}$ \\
\hline ADP/ATP & $2,2 \pm 0,2$ & $1,8 \pm 0,1$ & $2,2 \pm 0,9$ & $2,2 \pm 0,6$ & $2,1 \pm 0,3$ & $2,3 \pm 0,4$ & $2,1 \pm 0,2$ & $1,7 \pm 0,1$ & $2,5 \pm 0,6$ & $2,4 \pm 0,1$ & $1,8 \pm 0,1$ & $2,3 \pm 0,1$ \\
\hline $\begin{array}{l}\text { GSH/(GSH } \\
+ \text { GSSH) }\end{array}$ & $\begin{array}{l}91,3 \pm \\
9,5\end{array}$ & $\begin{array}{l}96,2 \pm \\
14,5\end{array}$ & $\begin{array}{l}96,3 \pm \\
7,1\end{array}$ & $\begin{array}{l}95,1 \pm \\
8,2\end{array}$ & $\begin{array}{l}93,2 \pm \\
10,4\end{array}$ & $\begin{array}{l}85,7 \pm \\
5,2\end{array}$ & $\begin{array}{l}96,9 \pm \\
8,5\end{array}$ & $\begin{array}{l}92,1 \pm \\
7,5\end{array}$ & $\begin{array}{l}96,6 \pm \\
3,0\end{array}$ & $91,6 \pm 6,1$ & $\begin{array}{l}79,5 \pm \\
20,4\end{array}$ & $\begin{array}{l}78,5 \pm \\
10,3\end{array}$ \\
\hline $\begin{array}{l}\text { Asc/(Asc } \\
+\mathrm{DHA})\end{array}$ & $\begin{array}{l}74,5 \pm \\
4,1\end{array}$ & $\begin{array}{l}73,1 \pm \\
1,2\end{array}$ & $\begin{array}{l}78,6 \pm \\
2,4\end{array}$ & $\begin{array}{l}75,6 \pm \\
2,2\end{array}$ & $\begin{array}{l}68,9 \pm \\
4,0\end{array}$ & $\begin{array}{l}71,2 \pm \\
5,3\end{array}$ & $\begin{array}{l}69,1 \pm \\
2,2\end{array}$ & $\begin{array}{l}67,8 \pm \\
4,4\end{array}$ & $\begin{array}{l}74,5 \pm \\
3,4\end{array}$ & $74,2 \pm 2,8$ & $\begin{array}{l}72,9 \pm \\
2,9\end{array}$ & $\begin{array}{l}53,2 \pm \\
4,0 *\end{array}$ \\
\hline
\end{tabular}

WT and npq1/ut2 rosettes were pre-treated for $48 \mathrm{hrs}$ at $10^{\circ} \mathrm{C}$ (see methods for details), then were exposed to photoxidative conditions (1000 $\mu$ mol photon $\mathrm{m}^{-2} \mathrm{~s}$ $1,10^{\circ} \mathrm{C}, 16 \mathrm{~h}$ light $/ 8 \mathrm{~h}$ dark). Leaves were harvested, then used for analysis of chlorophyll fluorescence parameters or immediately frozen in liquid nitrogen for measurements of metabolites, at the same time of the day over a 6-day-long stress period. Abbreviations: qP, photochemical quenching; Fv/Fm, maximal PSII photochemical efficiency; GSH/GSSG, glutathione reduced/oxidized; Asc, ascorbate; DHA, dehydroascorbate. Values that differ significantly between wild type and npq1lut2 mutant plants (Student's t-test, $\mathrm{p}<0.02$ ) are marked by an asterisk.

repressed in wild-type compared to mutant plants, with a similar tendency observed for other probe sets such as D2 and PsaA, for which down-regulation or no modulation was observed in wild-type plants while up-regulation was observed in the mutant. These finding indicate that the main response to excess light at low temperatures is a general repression of photosynthesis-related genes, but HL treatment in mutant leaves results in specific transcriptional re-programming of the core subunits of both photosystems, relieving the transcriptional repression in wild-type leaves. Biochemical analysis of thylakoid pigment-protein composition during stress treatment showed that the photosynthetic machinery acclimates by reducing the PSII/PSI ratio (Figure 4E), but there is little change in the antenna size as detected by the LHCII/PSII ratio (Figure 4F). These results agree with previous reports showing that when PSII becomes rate-limiting for photosynthetic electron transport, changes in photosystem stoichiometry occur to counteract this inefficiency [32]. Although the redox state of PQ is the same in both genotypes (Table 4), genes encoding PS core complexes are differentially expressed and there are differences in the rate at which the PSII/ PSI ratio declines. The faster reduction in the PSII/PSI ratio in mutant leaves, independent of PQ redox state or PSII photoinhibition (Table 4), suggests a ROS-dependent signal transduction pathway that facilitates the acclimatory modulation of thylakoid composition.

\section{Chloroplast reorganization in response to ${ }^{1} \mathrm{O}_{2}$ accumulation}

Several signals are thought to pass from the plastid, either directly or indirectly, through the cytoplasm to the nucleus, where they modulate gene expression under stress [25]. After acetonic extraction, pigment analysis showed that the chlorophyll $\mathrm{a} / \mathrm{b}$ ratio was higher in the mutant than the wild-type and this difference increased under stress (Figure 4A), reflecting the changing PSII/PSI ratio in the mutant upon HL treatment (Figure 4E) rather than a reduction in antenna size (Figure 4F). Under stress, $L h c$ transcription was inhibited to the same extent in both genotypes, whereas photosystem core genes were down-regulated more strongly in the wild-type plants. This is consistent with the significant increase in the $\mathrm{Chl} \mathrm{a} / \mathrm{b}$ ratio observed in the mutant, but there was no modulation of Ftsh expression to explain the more rapid degradation of pigment-protein complexes (Additional file 1: Table S6). The Chl/Car ratio differs significantly between the two genotypes, with wild-type plants showing a $24 \%$ reduction under stress, and mutants showing a $38 \%$ reduction (Figure 4B). Evidence for oxidative stress was found in the pattern of antioxidant compounds, e.g. glutathione S-transferase, methionine sulfoxide reductase and tocopherol (Additional file 1: Table S6). Several genes showing induction in npq1lut2 only encoded chloroplast proteins, that might be involved in cell protection against the damaging effect of ROS (Figure 5). Since most were induced after $24 \mathrm{~h}$ in the mutant, it suggests that induction occurs only when ${ }^{1} \mathrm{O}_{2}$ accumulation exceeds a threshold level (Additional file 1: Table S7).

\section{Discussion}

We have carried out a comparative analysis of wild-type Arabidopsis plants and the double mutant npq1lut2 in terms of mRNA levels, metabolite levels and physiological functions in response to conditions leading to oxidative stress. The npq1lut2 xanthophyll biosynthesis mutant was used to study the effect of ${ }^{1} \mathrm{O}_{2}$ accumulation on physiological stress responses $[47,49]$. This mutant lacks violaxanthin de-epoxidase (NPQ1) and lycopene- $\varepsilon$-cyclase (LUT2) activities, and is susceptible 


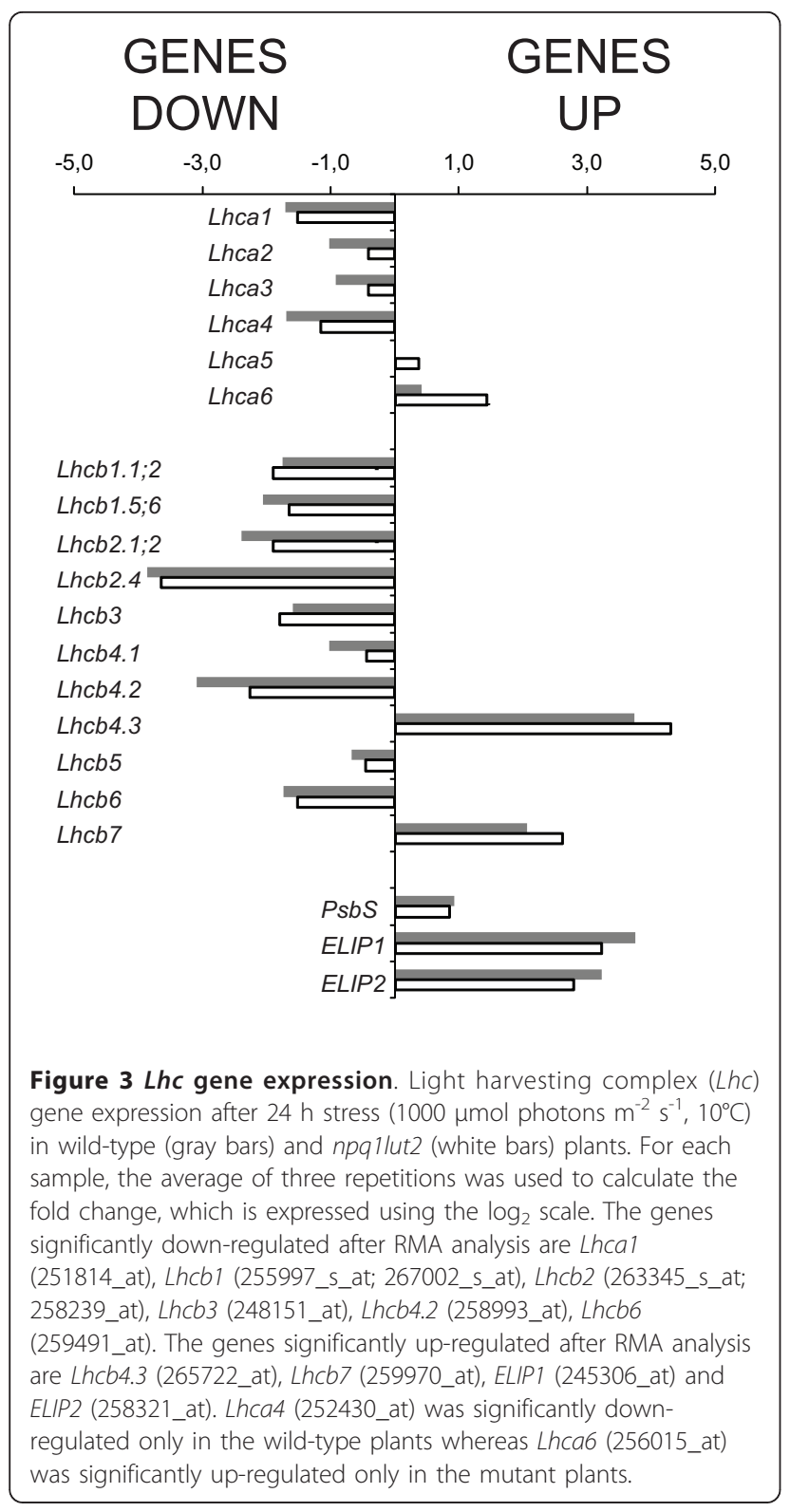

to photooxidative stress when exposed to excess light at low temperatures [47]. Under normal growth conditions the gene expression profile of the mutant is almost identical to that of wild-type plants, but differences become evident following exposure to excess light $(1000 \mu \mathrm{mol}$ $\left.\mathrm{m}^{-2} \mathrm{~s}^{-1}\right)$ at low temperature $\left(10^{\circ} \mathrm{C}\right)$. At time 0 (before stress), 18 genes were down-regulated in the mutant relative to wild-type plants, although the expression of those genes could be directly or indirectly regulated by the absence of lutein and zeaxanthin. Also, during high light treatments lutein and zeaxanthin could play a signalling role, directly or by compounds derived from them. The effect of individual carotenoids on transcription has not been analyzed in detail, but it is clear that the carotenoid content of the chloroplast affects gene expression under both normal and stress conditions, and affects chloroplast to nucleus communication $[13,73,74]$. Here, we show that ${ }^{1} \mathrm{O}_{2}$ accumulation in response to excess illumination within the physiological range is perceived as a signal to regulate significant number of nuclear genes encoding chloroplast proteins, facilitating acclimation to stress, but is not sufficient to induce apoptosis.

\section{Xanthophyll mutants are valuable for the analysis of ${ }^{1} \mathrm{O}_{2}$ signalling}

The suitability of the lut2npq1 mutant for the analysis of ${ }^{1} \mathrm{O}_{2}$ signaling was confirmed by comparing physiological parameters and ROS accumulation in relation to wild-type plants. Previous results $[47,75,76]$ showed that lut 2 mutation in Arabidopsis only affected few physiological parameter (increase in PSII/PSI and $\mathrm{Chl} \mathrm{a} / \mathrm{b}$ ratios, reduced efficiency of state transitions and LHCII trimerization); however, photosynthetic efficiency and growth rate in lut 2 plants were indistinguishable from wildtype. We cannot exclude that differences between the two genotypes at the onset of HL treatment could be responsible of some of the differential responses at transcriptome level. However, WT and npq1lut2 accumulate different amounts of ${ }^{1} \mathrm{O}_{2}$ from their chloroplasts before stress treatment (Figure 2, $\mathrm{T}=0$ ) as further confirmed by transcript levels at time 0 showing no major differences in gene regulation between WT vs mutant. Therefore, if a differential ${ }^{1} \mathrm{O}_{2}$ accumulation occurs even in low light, it is below the threshold level that makes ${ }^{1} \mathrm{O}_{2}$ a signal in the regulation of gene expression.

Present results demonstrate that ${ }^{1} \mathrm{O}_{2}$ is the only ROS differentially accumulated in the mutant with respect to WT upon HL treatment, while this mutations does not differentially affect the main parameters that, until now, have been related to gene expression regulation in HL. Indeed, following illumination at $1000 \mu \mathrm{mol} \mathrm{m} \mathrm{m}^{-2} \mathrm{~s}^{-1}$ and $10^{\circ} \mathrm{C}$, the photosynthetic electron transport chain was reduced to the same extent in both genotypes (Table 4). This allowed us to monitor the impact of excess light on the redox state of the PQ pool, a physiological parameter that has been proposed to have a specific role in chloroplast to nucleus signalling during stress acclimation [32]; therefore, the differential gene expression in wild-type $v s$ mutant plants cannot be attributed to changes in the PQ redox state, confirming data from previous studies [35]. Additional proposed signalling molecules, such as reduced forms of ROS, the redox state of the stoma redox component (GSH/GSSG, Asc/ Asc+DHA), and the ATP/ADP ratio [67] were indistinguishable in the two genotypes (Table 4 and Additional file 2: Figure S3), suggesting they are not major transcriptional regulators in response to photo-oxidative 
Table 5 Photosystem II and photosystem I genes

\begin{tabular}{llll}
\hline Locus identifier & Description & Fold Changes in WT & Fold Changes in npq1lut2 \\
\hline ATCG00680 & CP47, subunit of PSII reaction centre & -0.9 & -0.1 \\
ATCG00020 & D1, subunit of PSII reaction centre & 0.3 & 0.5 \\
ATCG00270 & D2, subunit of PSII reaction centre & -0.1 & 0.5 \\
ATCG00430 & Photosystem II G protein & -0.8 & 0.1 \\
ATCG00080 & Photosystem II I protein & -1.0 & -0.7 \\
ATCG00070 & Photosystem II K protein & $-1.4^{*}$ & -0.9 \\
AT4G05180 & PSBQ2, oxygen-evolving enhancer protein 3 & $-1.9^{*}$ & $-1.4^{*}$ \\
\hline AT5G64040 & PsaN & $-1.2^{*}$ & -0.4 \\
AT1G03130 & PsaD & $-2.0 *$ & $-1.0 *$ \\
AT2G20260 & PsaE & -1.7 & -1.0 \\
ATCG00350 & PsaA & 0.0 & 0.8 \\
ATCG00340 & PsaB & 0.1 & 0.6 \\
AT1G08380 & PsaO & $-1.6 *$ & -0.9 \\
AT1G31330 & PsaF & -1.0 & -0.7 \\
\hline
\end{tabular}

This table presents the subset of genes belonging to each photosystem core complex. The ratio between npq1/ut2 and wild-type plants after $24 \mathrm{~h}$ stress is expressed as a $\log _{2}$ scale. Marked fields represent probe sets with a significant changes after RMA analyses.

stress conditions used in this report. Therefore, all data presented suggest that gene expression changes described could be reasonably ascribed to singlet oxygen, even if we cannot exclude that other factors could act as signal in npq1lut2 plants, together with singlet oxygen, in the modulation of gene expression.

The npq1lut2 mutant shows a selective loss of lutein, which is active in ${ }^{3} \mathrm{Chl}^{*}$ quenching [47], and of zeaxanthin, which is an ${ }^{1} \mathrm{O}_{2}$ scavenger $[47,48,77,78]$, therefore the mutant specifically accumulates ${ }^{1} \mathrm{O}_{2}$ but not other ROS (Figure 2C) [47,79]. It should be noted that the change in xanthophyll composition marginally affects the composition of the photosynthetic apparatus in the mutant [47] while photosynthetic electron transport and growth rate are the same in both genotypes, therefore ${ }^{1} \mathrm{O}_{2}$ steady-state accumulation in the npq1lut2 mutant occurs only in response to excess light conditions (Figure 1 and Additional file 1: Table S4). Thus, npq1lut2 compares favourably with the flu mutant [29] in which ${ }^{1} \mathrm{O}_{2}$ is produced through the accumulation of $\mathrm{Chl}$ biosynthesis precursors, eventually leading to complete chloroplast bleaching. The present study on npq1lut2 is the first case in which ROS generation has been elicited in its natural site (i.e. within thylakoid membranes) rather than provided from outside or produced by photosensitizing metabolic precursors soluble in the chloroplast stroma. The level of PSII photoinhibition we found in npq1lut2 is not dramatic, since the photochemical efficiency of the mutant starts to acclimate to the stressing conditions after 4 days of $\mathrm{HL}$ (Table 4). In the flu mutant, over-accumulation of the photosensitizer Pchlide results in a stronger photosensitive phenotype, with extensive cell death as early as $1 \mathrm{~h}$ after the onset of illumination, and visible necrotic lesions formed 2 to $3 \mathrm{~h}$ later. Clearly, the level of stress applied in our experiment is far lower from that described in (Op den Camp et al. Plant Cell 2003) and is followed by a successful acclimative response as in a physiological response. Therefore we strongly support the notion that in our experimental conditions, ${ }^{1} \mathrm{O}_{2}$ acts primarily as a signal that modulates chloroplast acclimation to photoxidative stress.

The photosynthetic parameters and metabolic indicators discussed above (i.e. $\mathrm{F}_{\mathrm{v}} / \mathrm{F}_{\mathrm{m}}, \mathrm{Chl} \mathrm{a} / \mathrm{b}$ and $\mathrm{Chl} / \mathrm{Car}$ ratios, PSI/PSII ratio) show that the chloroplast function and communication between the chloroplast and cytoplasm are impaired in the mutant, while the differential expression of nuclear genes encoding chloroplast proteins confirms that the chloroplast is a central switch of the plant's response to cold and light stress $[13,74]$. We can now decipher the contribution of ${ }^{1} \mathrm{O}_{2}$ signalling to the stress acclimation response. A similar system was previously used with the mutant npq1lor 1 of the green alga Chlamydomonas reinhardtii. Nevertheless, in Arabidopsis we identified a fast component of gene expression regulation by ${ }^{1} \mathrm{O}_{2}$ at $2 \mathrm{~h}$ that was not detected in Chlamydomonas [80].

The npq1lut2 transcriptome integrates the ROS signalling network

Oxidative stress is a complex process that can be triggered by a range of environmental, biotic and developmental factors. It is therefore not surprising that different pathways can be induced, depending on the nature of the stress. Previous studies using a catalasedeficient mutant exposed to excess light identified genes that are differentially expressed in response to $\mathrm{H}_{2} \mathrm{O}_{2}$ accumulation, leading to the discovery that $\mathrm{H}_{2} \mathrm{O}_{2}$ 

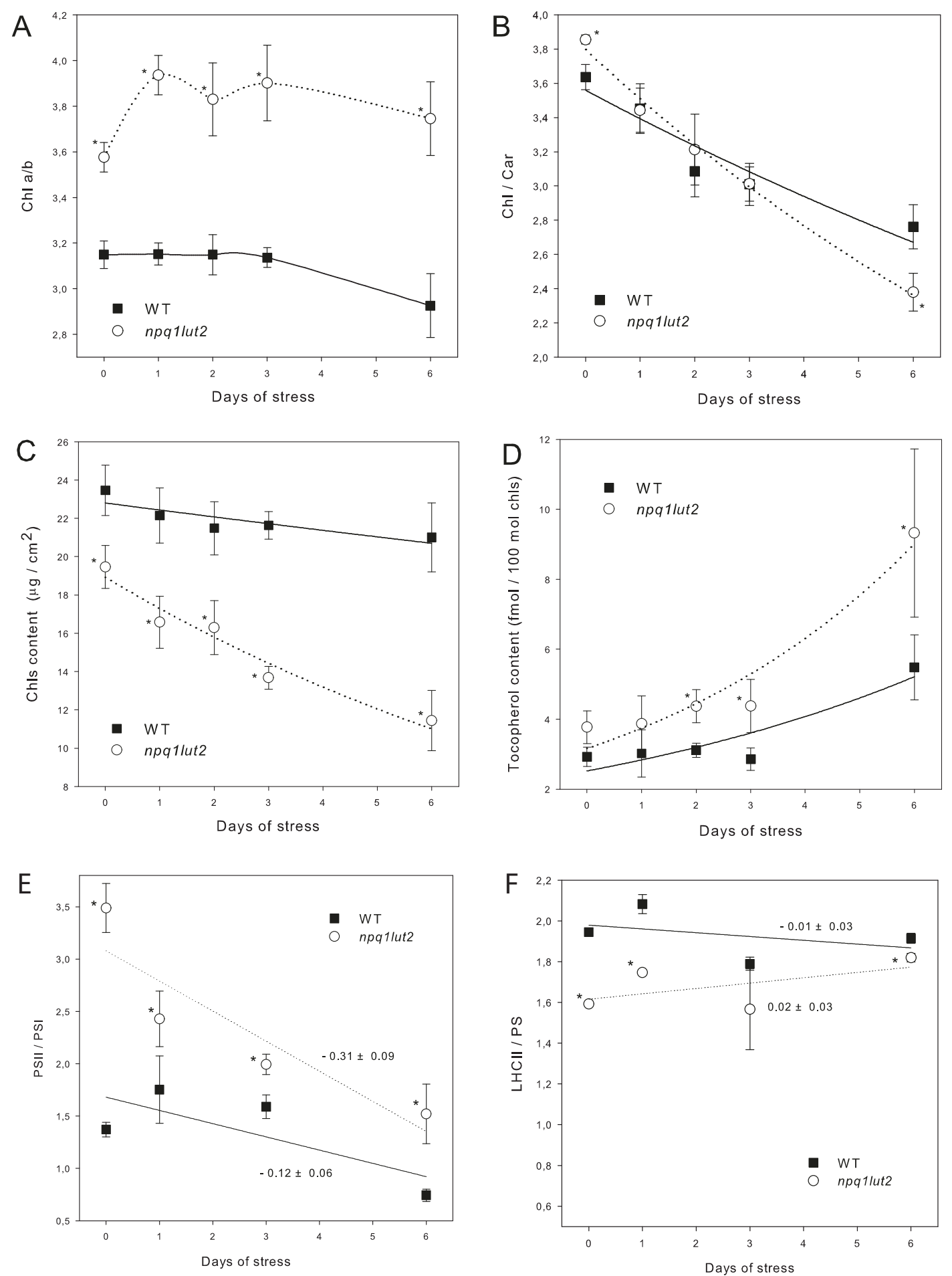

Figure 4 Biochemical characterization of thylakoid membrane composition under high light stress. Chlorophylls ( $A, C)$, carotenoids (B) and tocopherol (D) content of WT and lut2npq1 plants were measured on leaf acetone extracts as described in "Material and Methods". (E, F) Stoichiometry between photosynthetic pigment-binding complexes under high light stress. PSII/PSI ratio (E) and biochemical antenna size (LHCII/ PS ratio, F) were determined by both non-denaturing Deriphat-PAGE and immunoblot-titration using specific antibodies (see "Material and Methods" for details). Symbols and error bars show respectively means \pm SD. 


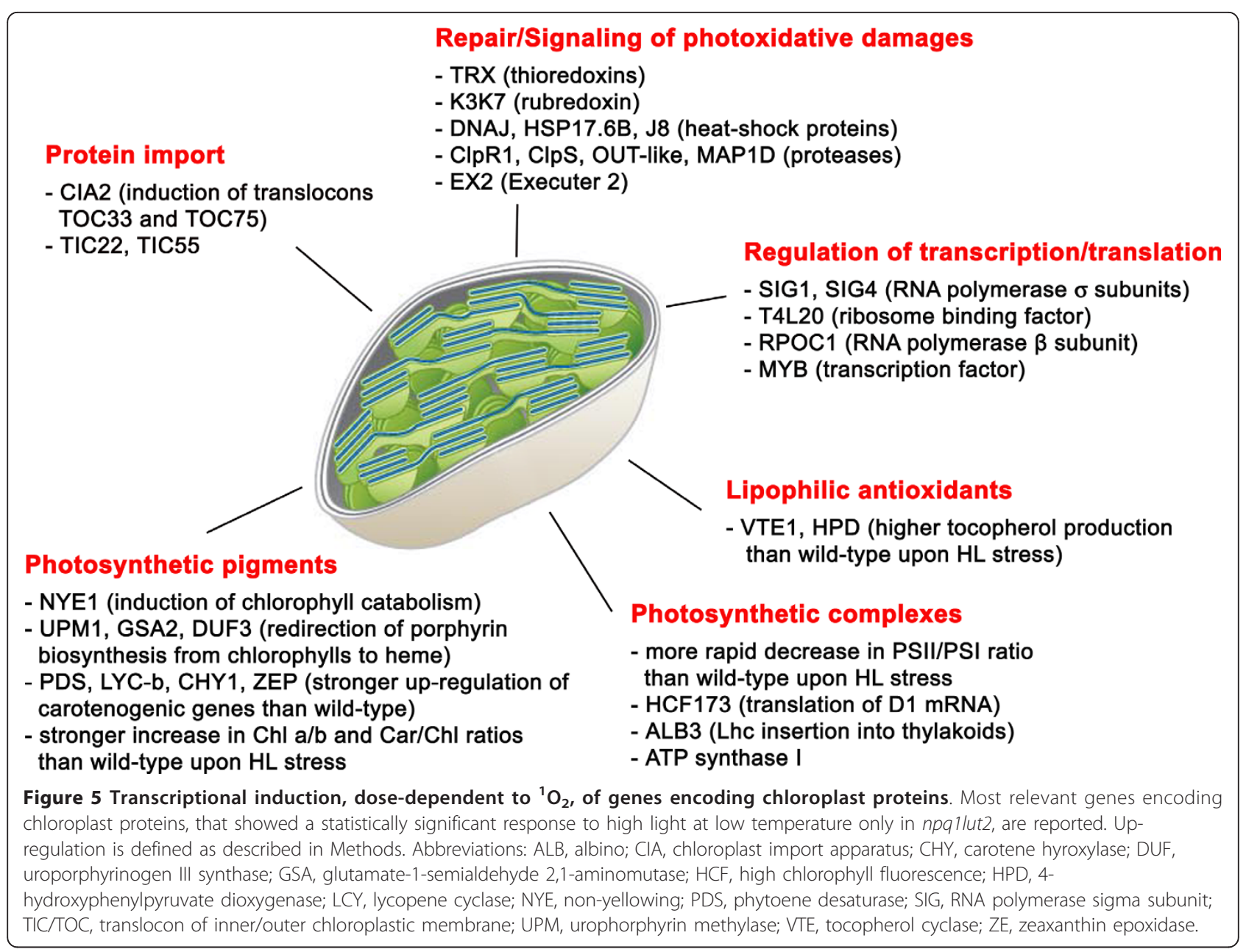

regulates anthocyanin biosynthesis [28]. Several reports have also proposed that ${ }^{1} \mathrm{O}_{2}$ has a signalling role $[81,82]$.

Here we have determined the photoprotective effect of two xanthophylls when plants are exposed to excess light at low temperatures. Only 18 genes were found to be differentially expressed between wild type plants and the npq1lut2 mutant under normal conditions, probably reflecting the absence of lutein and zeaxanthin in the mutant (Additional file 1: Table S4). However, when the plants were exposed to excess light at a low temperature, a group of 67 genes encoding chloroplast proteins was specifically repressed in wild type plants, whereas the same genes were not affected in the mutant. This is intriguing because a nuclear mutation affecting chloroplast xanthophyll composition is clearly able to regulate gene expression and ultimately chloroplast acclimation. We can thus conclude that the expression of some nuclear genes depends on the xanthophyll content directly or indirectly, via its impact on ${ }^{1} \mathrm{O}_{2}$ accumulation (Figure 2C). We do not exclude that lutein, zeaxanthin and products of their metabolisms play a signalling role under stress. Indeed, carotenoids can play a clear signalling role [83]. Here we want to highlight the correlation between gene expression regulation and ${ }^{1} \mathrm{O}_{2}$ steady-state accumulation in a mutant lacking two photoprotective xanthophylls. One possibility is that a subset of genes in Table 2 responds to the change in ${ }^{1} \mathrm{O}_{2}$ accumulation within the thylakoid membranes, e.g. those encoding glutaredoxin (AT1G03850), ATP-dependent protease La (AT1G75460), DNAJ heat shock N-terminal (AT4G13830) and enzymes involved in phylloquinone and plastoquinone biosynthesis (AT1G60600). Functional annotation of the 38 uncharacterized genes in this list will help further to decipher how gene regulation by lutein and zeaxanthin occurs under oxidative stress, as shown in previous studies $[84,85]$.

One group of genes specifically modulated in the npq1lut2 mutant overlaps with those regulated in $\mathrm{flu}$ (Additional file 1: Table S8), a reference mutant used in the study of ${ }^{1} \mathrm{O}_{2}$ signals $[50,86]$ in agreement with the high level of ${ }^{1} \mathrm{O}_{2}$ accumulation measured in npq1lut2 (Figure 2C). Also in the attempt of comparing the 
response in $n p q 1$ lut1 vs $f l u$, we performed a more sophisticated statistical analysis comparing npq1lut2 transcriptome and flu/executer transcriptome [53]. The conditions used in the two experiments are different as demonstrated by the high number of genes (2420 probe-sets) differentially expressed in the two wild-types (Additional file 2: Figure S4A). A low level of overlap between npq1lut2 and flu/executer transcript response was detectable (Additional file 2: Figure S4B) showing that transcriptomic analysis performed in different labs under different experimental conditions must be compared with precaution as shown by previous papers $[7,36]$. Comparative transcriptomic analysis of the ${ }^{1} \mathrm{O}_{2}$ response signature showed that the cluster of genes regulated by ${ }^{1} \mathrm{O}_{2}$ in both flu and npq1lut 2 is not modulated in all oxidative stress cases analyzed to date. However, we identified a subset of genes affected by ${ }^{1} \mathrm{O}_{2}$ and $\mathrm{O}_{3}$, whereas there is negative correlation between the genes modulated by ${ }^{1} \mathrm{O}_{2}$ and those modulated by $\mathrm{H}_{2} \mathrm{O}_{2}$ (Table 6). This antagonistic transcriptional regulation mediated by ${ }^{1} \mathrm{O}_{2}$ and $\mathrm{H}_{2} \mathrm{O}_{2}$ supports previous data showing cross-talk and antagonistic $\mathrm{H}_{2} \mathrm{O}_{2}$ and ${ }^{1} \mathrm{O}_{2}$ signalling in $f l u$ mutants under stress overexpressing the thylakoid-bound ascorbate peroxidase [30]. The molecular basis of these opposing responses appears to reflect the presence of specific cis-regulatory elements responsive to either ${ }^{1} \mathrm{O}_{2}$ or $\mathrm{H}_{2} \mathrm{O}_{2}$ within the corresponding promoters [87]. A new and close relationship among ROS was recently demonstrated, where each ROS species activates a specific response, but the pathways converge to produce a clear ${ }^{1} \mathrm{O}_{2}$ signature in lipid peroxidation [52].

The genome-wide hypersensitive response is more strongly induced in flu mutants than in npq1lut2 mutants (Additional file 1: Table S9). Among 369 genes significantly up-regulated following infection with Pseudomonas DC3000 (avrRpm1) [88], 292 were also detected in the $f l u$ and $n p q 1 l u t 2$ transcriptomes with 267 induced in flu and only 69 in npq1lut2 (resulting in a far less pronounced apoptotic response). In agreement with this, we did not observe cell death in Arabidopsis plants by vital staining and DNA fragmentation analysis (data not shown). Because npq1lut2 specifically showed higher ${ }^{1} \mathrm{O}_{2}$ steady-state accumulation (Figure 2), this implies that cell death is not a specific or immediate response to ${ }^{1} \mathrm{O}_{2}$ in the absence of the most effective photoprotection mechanisms present in wild-type plants, at least under our experimental conditions. However, we cannot exclude the possibility that higher levels of ${ }^{1} \mathrm{O}_{2}$ accumulated under non-physiological conditions, might induce cell death.

Recent work by Apel and co-workers revealed that EXECUTER genes are involved in the early response to ${ }^{1} \mathrm{O}_{2}$ in Arabidopsis by the transduction of ${ }^{1} \mathrm{O}_{2}$ signals from the chloroplast to the nucleus in the $f l u$ mutant $[51,53] .{ }^{1} \mathrm{O}_{2}$ accumulation in npq1lut 2 induced the expression of ex2 but not ex1, but there was no effect in similarly-treated wild-type plants, confirming that ${ }^{1} \mathrm{O}_{2}$ oxygen signals are measurable in the npq1lut2 transcriptome and that EX1 and EX2 might respond differently to environmental cues.

\section{Xanthophylls modulate the pigment composition of thylakoid membranes}

It is well documented that plants acclimate to different light conditions by regulating their carotenoid composition [89]. It is worth noting that the higher rate of ${ }^{1} \mathrm{O}_{2}$ accumulation in npq1lut 2 plants corresponds to the induction of genes representing the $\beta-\beta$ branch of carotenoid biosynthesis ( $\beta$-carotene hydroxylase, zeaxanthin epoxidase, lycopene $\beta$-cyclase; Table S5). In thylakoid membranes, the accumulation of $\beta-\beta$ xanthophylls would increase the ability of plants to synthesize zeaxanthin and neoxanthin when needed, thus facilitating the response to excess light. Indeed, these $\beta-\beta$ xanthophylls have both an important role in photoprotection [90-92] and mutants lacking such compounds undergo irreversible photo-oxidation when exposed to excess light [90]. Growth under intense light caused carotenoid levels to increase in npq1lut2 plants compared to the wild-type (Figure 4B), and because carotenoids scavenge ${ }^{1} \mathrm{O}_{2}$ or directly quench ${ }^{3} \mathrm{Chl}^{*}$, the increased $\mathrm{Car} / \mathrm{Chl}$ ratio appears to be a protective mechanism $[20,93]$.

Besides carotenoids, plants synthesize other antioxidants such as tocopherol (vitamin E). This lipophylic compound is localized exclusively in the lipid phase of the thylakoid membranes, and is an active ${ }^{1} \mathrm{O}_{2}$ scavenger $[10,94]$. Higher levels of tocopherol were observed in the leaves of $n p q 1$ mutant plants after $3 \mathrm{~d}$ of excess light stress [95], and it was proposed to have a primary role in the prevention of lipid peroxidation promoted by ${ }^{1} \mathrm{O}_{2}$. We found that npq1lut2 plants under chilling stress accumulated tocopherols to higher levels than wild-type plants when exposed to excess light for $6 \mathrm{~d}$ (Figure 4D) and contained $\sim 70 \%$ more $\alpha$-tocopherol. Tocopherol synthesis is therefore strongly induced by excess light in the mutant, particularly given the rapid consumption due to the increased rate of ROS accumulation. The biochemical analysis was consistent with the transcriptomic data, showing stronger and faster induction of tocopherol synthesis genes in the mutant, e.g. HPD (AT1G06570) and VTE1 (AT4G32770) (Additional file 1: Table S6).

Tetrapyrrole synthesis must also be regulated under excess light stress to prevent damage to the photosynthetic machinery, and when photo-oxidative stress accelerates the degradation of pigment-protein complexes, the synthesis of chlorophyll must slow down to 
Table 6 Expression of genes up- and down-regulated in different ROS accumulating conditions

\begin{tabular}{|c|c|c|c|c|c|c|c|c|c|c|c|}
\hline \multicolumn{12}{|c|}{ UP regulated } \\
\hline Probeset & $\begin{array}{l}\text { Locus } \\
\text { identifier }\end{array}$ & flu & $n 1 / 2$ & Ozono & $\begin{array}{r}\text { MV } 2 \\
\mathrm{~h}\end{array}$ & $\begin{array}{r}\text { MV } 4 \\
\text { h }\end{array}$ & vte2 & vte1 & cat & DCMU & Description \\
\hline 253259_at & At4g34410 & 6,60 & 1,29 & 2,17 & 1,21 & $-0,24$ & $-1,13$ & 0,20 & $-2,93$ & $-0,62$ & RRTF1, AP2 domain-containing transcription factor \\
\hline 253832_at & At4g27654 & 6,23 & 1,02 & 0,77 & 0,53 & 1,53 & 0,88 & 1,29 & $-3,59$ & & unknown protein \\
\hline 248793_at & At5g47240 & 5,78 & 1,17 & 2,21 & 0,35 & 1,04 & 0,20 & $-0,11$ & $-2,20$ & & ATNUDT8, Nudix hydrolase homolog 8 \\
\hline 247360_at & At5g63450 & 5,51 & 1,21 & 1,47 & 2,84 & 1,08 & 0,19 & $-0,80$ & $-0,81$ & & CYP94B1, oxygen binding cytochrome P450 \\
\hline 266821_at & At2g44840 & 5,40 & 1,03 & 2,60 & 2,75 & 1,79 & 0,28 & 0,36 & $-2,74$ & $-0,40$ & Ethyne responsive element binding factor 13 \\
\hline 262354_at & At1g64200 & 4,82 & 2,21 & 1,36 & $-0,10$ & 0,23 & $-0,02$ & $-0,50$ & 0,03 & & Vacuolar H+-ATPase subunit 3 \\
\hline 247030_at & At5g67210 & 4,62 & 1,22 & 1,19 & $-0,33$ & 0,11 & $-0,10$ & $-2,48$ & $-1,03$ & & nucleic acid binding/putative ribonuclease \\
\hline 256021_at & At1g58270 & 3,92 & 4,23 & 0,36 & 0,30 & $-0,60$ & 0,41 & $-0,18$ & $-0,80$ & & ZW9 \\
\hline 266977_at & At2g39420 & 3,66 & 1,45 & 1,63 & 0,26 & $-0,05$ & $-0,10$ & 0,27 & $-0,75$ & $-0,34$ & esterase/lipase/thioesterase family protein \\
\hline 255941_at & At1g20350 & 3,33 & 1,46 & 4,30 & 0,30 & $-0,18$ & $-2,10$ & 1,05 & 1,08 & & TIM17, mitochondrial inner membrane translocase \\
\hline 263320_at & At2g47180 & 3,10 & 1,10 & 1,71 & $-0,24$ & 0,82 & 2,04 & 0,99 & $-0,36$ & & AtGOLS1 Galactinol Synthase 1 \\
\hline 266418_at & At2g38750 & 2,47 & 1,31 & 0,80 & $-0,42$ & $-0,69$ & 1,04 & $-1,97$ & 0,09 & $-0,43$ & ANNAT4, Annexin Arabidopsis 4; calcium ion binding \\
\hline 264986_at & At1g27130 & 2,46 & 1,07 & 1,52 & $-0,08$ & 0,72 & $-0,21$ & $-0,36$ & 0,52 & & ATGSTU13, glutathione S-transferase 13 \\
\hline
\end{tabular}

\begin{tabular}{|c|c|c|c|c|c|c|c|c|c|c|}
\hline \multicolumn{11}{|c|}{ DOWN regulated } \\
\hline Probeset & $\begin{array}{l}\text { Locus } \\
\text { identifier }\end{array}$ & flu & $n 1 / 2$ & Ozono & $\begin{array}{r}\text { MV } 2 \\
h\end{array}$ & $\begin{array}{r}\text { MV } 4 \\
\text { h }\end{array}$ & vte2 & vte1 & cat DCMU & Description \\
\hline 247638_at & At5g60490 & $-2,44$ & $-0,92$ & 0,01 & $-0,22$ & 0,17 & 0,30 & 0,60 & 0,17 & $\begin{array}{l}\text { FLA12_FLA12 (fasciclin-like arabinogalactan-protein } \\
\text { 12) }\end{array}$ \\
\hline 252573_at & At3g45260 & $-2,38$ & $-0,37$ & 0,19 & 0,73 & 0,37 & $-0,43$ & 0,13 & 0,05 & zinc finger ( $\mathrm{C} 2 \mathrm{H} 2$ type) family protein \\
\hline 258370_at & At3g14395 & $-2,46$ & $-0,69$ & 0,07 & $-2,76$ & $-0,01$ & $-0,03$ & 1,29 & 0,47 & unknown protein \\
\hline 255149_at & At4g08150 & $-2,85$ & $-0,97$ & $-0,23$ & $-1,98$ & 1,33 & 0,25 & $-0,10$ & $-0,38$ & $\begin{array}{l}\text { KNAT1_BP_KNAT1 (BREVIPEDICELLUS 1); } \\
\text { transcription factor }\end{array}$ \\
\hline 259903_at & At1g74160 & $-2,34$ & $-0,72$ & 0,26 & $-0,26$ & 0,16 & 0,05 & 0,25 & $-0,58$ & unknown protein \\
\hline 262783_at & At1g10850 & $-2,47$ & $-0,37$ & $-0,27$ & 0,07 & 0,41 & $-0,21$ & $-0,67$ & $-0,10$ & ATP binding/protein serine/threonine kinase \\
\hline 261883_at & At1g80870 & $-2,43$ & $-0,48$ & $-0,55$ & $-0,36$ & $-0,01$ & 0,84 & 0,85 & 0,44 & protein kinase family protein \\
\hline 247463_at & At5g62210 & $-2,77$ & $-0,91$ & $-1,24$ & 1,16 & $-0,22$ & 0,36 & $-1,72$ & $-1,66$ & embryo-specific protein-related \\
\hline 252746_at & At3g43190 & $-3,53$ & $-0,51$ & 0,19 & 0,89 & $-0,40$ & $-0,31$ & $-1,83$ & $-0,10$ & $\begin{array}{l}\text { SUS4_SUS4; UDP-glycosyltransferase/sucrose } \\
\text { synthase }\end{array}$ \\
\hline 250891_at & At5g04530 & $-2,64$ & $-0,47$ & $-0,35$ & $-0,52$ & 0,27 & $-0,10$ & $-0,22$ & $-1,34$ & beta-ketoacyl-CoA synthase family protein \\
\hline 260693_at & At1g32450 & $-2,51$ & $-0,26$ & $-0,23$ & $-0,21$ & 0,22 & $-0,85$ & $-0,70$ & $-0,50$ & $\begin{array}{l}\text { proton-dependent oligopeptide transport (POT) } \\
\text { family protein }\end{array}$ \\
\hline 250344_at & At5g11930 & $-2,82$ & $-0,97$ & 0,14 & $-0,39$ & $-1,01$ & $-0,45$ & 0,38 & $-1,17$ & glutaredoxin family protein \\
\hline
\end{tabular}

The transcription regulation of genes specifically responding to ${ }^{1} \mathrm{O}_{2}$ in flu and npql/ut2 mutants was compared to various experiments by using mutants and/or treatments. The ratio between treated and control plants is expressed as a $\log _{2}$ scale. For each sample, the average of three repetitions was considered.

compensate. We therefore measured changes in the total $\mathrm{Chl}$ content as well as in $\mathrm{Chl} \mathrm{a/b}$ ratio. The tetrapyrrole pathway is regulated by metabolic intermediates at the transcriptional and post-translational levels [96]. In particular, heme is a well known repressor of early steps in the Chl synthesis pathway [97]. Crosstalk between tetrapyrrole biosynthesis and ${ }^{1} \mathrm{O}_{2}$ was demonstrated in flu mutants [98]. Our data clearly show that the higher levels of ${ }^{1} \mathrm{O}_{2}$ accumulation in npq1lut2 mutants promote the expression of heme oxygenase 3 (AT1G69720) and uroporphyrin III C-methyltransferase (AT2G26540), resulting in higher levels of heme in mutant compared to wild-type plants (Additional file 1: Table S5). Furthermore, repression of protochlorophyllide reductase B (AT4G27440) in npq1lut2 could limit chlorophyll production, helping to reduce the number of pigment-protein complexes in the cell during chloroplast acclimation to excess light.

${ }^{1} \mathrm{O}_{2}$ therefore appears to participate in a fine-tuning system that modulates chlorophyll biosynthesis and the accumulation of carotenoids and lipophylic antioxidant compounds in excess light stress, thereby increasing plant fitness under normal illumination.

\section{Xanthophylls affect the composition of the photosynthetic apparatus during acclimation}

Light-harvesting complexes respond rapidly to changes in environmental conditions [99]. We showed that most Lhc genes have similar expression profiles in wild type and npq1lut 2 mutant plants, even though they encode 
proteins that bind lutein and zeaxanthin. Many $L h c$ genes were down-regulated, with Lhcb2.4 the most strongly repressed (Figure 3 ). The exceptions were Lhcb4.3, Lhcb7, PsbS and ELIPs, consistent with data showing that the four corresponding antenna proteins participate in photoprotection $[69,100,101]$.

Interestingly, the different isoforms of Lhcb4 (CP29) were modulated in distinct ways despite their very similar polypeptide sequence. In particular, although Lhcb4.1 and Lhcb4.2 were down-regulated in both genotypes under stress conditions, Lhcb4.3 [102] was induced in both genotypes to the same extent. This is consistent with previous studies showing the evolutionary conservation of genetic redundancy in the $L h c$ superfamily [103], and it suggests that different CP29 polypeptides may play significant and specific roles in acclimation.

Our expression data also suggested that several signals intersect to regulate the $L h c$ superfamily and that transcriptional regulation is only one component of a more complex process. The most striking change in thylakoid composition under stress was the progressive reduction in the PSII/PSI ratio, which was more pronounced in npq1lut2 mutants (Table 5 and Figure 5). Such a reduction may be necessary to prevent the over-reduction of photosynthetic electron chains [20] and likely reflects changes to the rates at which the various substrates are synthesized and destroyed. PSII destruction is higher in the mutant because of the excessive photo-oxidation, and we have provided evidence that genes encoding several PSII core complex subunits (and to a lesser extent those in the PSI core complex) are induced in the mutant and repressed in wild-type plants (Table 5). It is well known that the transcription and the translation of PSII and PSI genes is extremely complex and often uncoupled. Analysis of the barley PSI-less viridis zb63 mutant showed an over-reduction of PQ pool and an increase in PSII core content into thylakoid with respect to WT (Frigerio 2007); all these changes in PSII content occurs without changes in PsaA mRNA levels. Furthermore, in the viridis $z b 63$ mutant, despite the absence of fully assembled PSI complex and the missed accumulation of any core polypeptides, all genes encoding PSI subunits are substantially expressed at the same level with respect to wild-type plants. These evidences suggest that a) regulation of photosystems accumulation could not only involve chronic PQ reduction [32] and b) regulation of composition of photosynthetic components could be mainly at the level of protein turn-over.

In contrast to previous reports [20], the loss of PSII content was not accompanied by a dramatic loss of bulk LHCII, probably because more time might be needed to achieve a functional antenna size final state under our growth conditions. Finally, ${ }^{1} \mathrm{O}_{2}$ induces chloroplast ATP synthase protein I (AT2G31040) specifically in npq1lut2 mutants after $24 \mathrm{~h}$ exposure to excess light, and a higher level of ATP synthase was previously identified as one of the long-term responses that facilitate chloroplast acclimation to intense light [104].

\section{Chloroplasts respond to the accumulation of ${ }^{1} \mathrm{O}_{2}$ by functional reorganization}

We found that several genes showing dose-dependent induction by ${ }^{1} \mathrm{O}_{2}$ encoded chloroplast proteins whose function is to protect cells against the damaging effect of ROS. Most were induced after $24 \mathrm{~h}$ specifically in the mutant, suggesting induction occurs only when ${ }^{1} \mathrm{O}_{2}$ accumulation exceeds a threshold level (Additional file 1: Table S7).

Many of these proteins were thioredoxins, ${ }^{1} \mathrm{O}_{2}$ quenching proteins that respond to oxidative stress [105]. This is consistent with previous reports showing that thioredoxins are protective proteins that maintain the cellular redox environment [106]. Others are involved in chlorophyll catabolism (At4g22920 and At5g13800), and their induction correlates with both the down-regulation of genes involved in tetrapyrrole biosynthesis (Table S5) and the accelerated reduction of chlorophyll levels in mutant leaves under excess light stress compared to similarly-treated wild type plants. Others encode heat shock proteins (Hsps-p23like, sHsps, DNAJ, J8) and proteases (Clp serine-type endopeptidase, ATP-dependent Clp protease, OUT-like cysteine protease, MAP1D Met-aminopeptidase), which function as molecular chaperones that suppress aggregation of proteins damaged by ROS, or to facilitate protein turnover (Table S7). Others are involved in either the synthesis or membrane-insertion of photosynthetic subunits, e.g. Hcf173 (At1g16720) is part of a thylakoid complex essential for the translation of $p s b \mathrm{~A}$ mRNA (encoding D1), and its induction in a mutant in which higher ${ }^{1} \mathrm{O}_{2}$ accumulation increases the rate of D1 turnover is consistent, and Alb3 (At2g28800) has a role in the insertion of a subset of light-harvesting complexes into thylakoids (Table S7). The induction of a lipase (At5g11650) and FAD7 (fatty acid desaturase 7, At3g11170) facilitates the production of jasmonic acid, an elicitor released by chloroplast membranes under photo-oxidative stress. EXECUTER2, whose role in coupling ${ }^{1} \mathrm{O}_{2}$ signalling from the chloroplast to nucleus has been described [53], was also up-regulated specifically in mutant plants.

The up-regulation of CIA2 (At5g57180) in the mutant after 2 and $24 \mathrm{~h}$ of excess light stress is particularly interesting because CIA2 is a transcription factor that specifically promotes the expression of genes encoding the translocon proteins Toc33 and Toc75, which are necessary for protein import into the chloroplast, and 
chloroplast ribosomal proteins [107]. In addition, both Tic22 (At5g62650) and Tic55 (At2g24820) were upregulated in the mutant, and these encode components of the translocon on the chloroplast inner envelope membrane. Taken together, these data suggest that ${ }^{1} \mathrm{O}_{2}$ plays a key role in fulfilling the increased demand for protein import into the chloroplast during photo-oxidative stress, reflecting the higher rate of protein damage and turnover, by co-ordinately up-regulating both protein import and translation [107].

\section{Conclusions}

Xanthophylls accumulated within thylakoid membranes are compounds that participate actively to ROS scavenging and to the prevention of ROS synthesis. Our data provide evidences that xanthophylls modulate ${ }^{1} \mathrm{O}_{2}$ dependent signals during the acclimation to high-light and low-temperature conditions. Indeed, in npq1lut 2 double mutant ${ }^{1} \mathrm{O}_{2}$ signalling facilitates the early finetuning of the expression of a group of genes encoding chloroplast proteins. This regulation does not correlate with the redox state of the PQ pool. Chloroplasts respond to these signals by a significant change in composition, resulting in rapid morphological and functional modifications. The response to ${ }^{1} \mathrm{O}_{2}$ does not include cell death, even in the highly photosensitive npq1lut2 mutant.

\section{Methods}

\section{Plant material and growth conditions}

Arabidopsis thaliana plants, wild-type and T-DNA insertion mutants (Columbia ecotype) npq1 (At1G44446) and lut2 (At5G57030) were obtained from NASC collections [108]. Mutant npq1lut2 was obtained by crossing single mutant plants and selecting progeny by pigment analysis [47]. Plants were grown in pots filled with homogenous non-enriched compost and watered weekly with Coïc-Lesaint nutrient solution [109]. They were grown in a growth chamber for 6 weeks under controlled conditions $(\sim 120 \mu \mathrm{mol}$ photons $\mathrm{m}^{-2} \mathrm{~s}^{-1}, 24^{\circ} \mathrm{C}, 8 \mathrm{~h}$ light $/ 16 \mathrm{~h}$ dark, $70 \%$ relative humidity).

\section{Micorarray experiments and statistical analysis of data}

Before transcriptomic analysis, 6 weeks old plants were transferred from controlled conditions above described to a cold chamber $\left(10^{\circ} \mathrm{C}\right)$ under low-light conditions $(25$ $\mu \mathrm{mol}$ photons $\mathrm{m}^{-2} \mathrm{~s}^{-1}$, continuous light) and maintained in this environment for $48 \mathrm{~h}$ in order to reduce the effect of the circadian clock [110]. Wild-type and npq1lut2 plants were then exposed to intense light $\left(1000 \mu \mathrm{mol}\right.$ photon $\left.\mathrm{m}^{-2} \mathrm{~s}^{-1}\right)$ using $150 \mathrm{~W}$ halogen lamps (Focus 3, Prisma, Verona, Italy) at $10^{\circ} \mathrm{C}$. Samples for transcriptome analysis were collected at 0,2 and $24 \mathrm{~h}$ of excess light treatment, and rapidly frozen in liquid nitrogen prior to RNA extraction.

Three biological replicates per treatment were analyzed by using the Affymetrix GeneChip ${ }^{\circledR}$ Arabidopsis ATH1 Genome Array, which contains more than 22,500 probe sets representing 24,000 gene-specific tags (about 80 are chloroplast genes). For each biological repetition, RNA samples for a condition/genotype were obtained by extracting RNA from the entire rosette of eight pooled plants. Total RNA was quantified and then adjusted to a final concentration of $1 \mu \mathrm{g} / \mu \mathrm{l}$. RNA integrity was assessed using the Agilent RNA 6000 nano kit and Agilent Bioanalyzer 2100 (Agilent Technologies, Palo Alto, CA). RNA samples were processed following the Affymetrix GeneChip Expression Analysis Technical Manual (Affymetrix, Inc., Santa Clara, CA). Scanned images were analyzed using the Gene Chip Operating Software v1.4. Expression analysis was carried out using default values. Quality control values, present calls, background, noise, scaling factor, spike controls, and the 3'/5' ratios of glyceraldehyde-3-phosphate dehydrogenase (AT3G04120) and actin (AT5G09810) showed minimal variation between samples. Raw data files (CEL files) were background-adjusted and normalized, and gene expression values were calculated using the Robust Multichip Analysis (RMA) [111] algorithm implemented in the statistical package R2.3.1 ( $\mathrm{R}$ foundation) with the dedicated "Affy" library [112].

The "Affy" library was used to run the MAS 5.0 algorithm on raw data to produce a detection call for each probe set. Because non-expressed genes ("absent") represent experimental noise and can generate false positives, all the probe sets failing to show three "present calls" in at least one sample were removed from the analysis. Normalized data were imported into the GenespringGX7.3.1 (Agilent Technologies, Santa Clara CA) software for analysis. Each gene was normalized to the median of the measurements.

To identify differentially expressed probe sets, we applied a Welch t-test with Benjamini and Hochberg false discovery rate correction for multiple tests [113]. Differences in gene expression were considered to be significant when $\mathrm{p}<0.05$ and the ratio of expression levels was at least two-fold [114]. Clusters of genes with distinctive expression patterns were searched applying two algorithms: k-means [115] and QT (Quality Threshold) cluster analysis [116]. QT clustering algorithm groups genes into high quality clusters based on two parameters: "minimum cluster size" and "minimum correlation". The minimum cluster size was set to 10 and minimum correlation to 0.75 (Pearson correlation). To determine if certain classes of genes were over-represented within selected clusters of genes compared to the functional categories on the entire array, the MIPS 
Arabidopsis thaliana database (MatDB) (mips.gsf.de/ projects/funcat) was employed [54].

Data from other experiments were obtained as additional data from published papers $[36,85]$ or downloaded from the European Bioinformatics Institute [117]. For published microarray data comparing a test sample and a control sample, genes were considered to be differentially expressed when they showed a $\log _{2}$ ratio of either $\geq 1$ or $\leq-1$ [7].

\section{Quantitative real-time PCR (qRT-PCR)}

Miroarray data were independently verified by qRTPCR, using $3 \mu \mathrm{g}$ total RNA from each sample. The RNA was reverse transcribed using an oligo(dT)18 primer with MoMLV Reverse Transcription Reagents (Promega) according to the manufacturer's standard protocol. The reaction was incubated at $40^{\circ} \mathrm{C}$ for $10 \mathrm{~min}$, then $45^{\circ} \mathrm{C}$ for $50 \mathrm{~min}$, and then at $70^{\circ} \mathrm{C}$ for $15 \mathrm{~min}$ to inactivate the reverse transcriptase. The cDNA was quantified using a QbitTM fluorometer (Invitrogen), diluted and used for q-PCR amplifications with specific primers.

Each qRT-PCR was performed with SYBR Green fluorescence detection in a qPCR thermal cycler (ABI PRISM 7300, Applied Biosystems). Each reaction was prepared using $5 \mu \mathrm{l}$ from a $0.2 \mathrm{ng} / \mathrm{mL}$ dilution of cDNA derived from the reverse transcription, $10 \mu \mathrm{l}$ of SYBR Green PCR Master Mix (Applied Biosystems), and 0.5 $\mu \mathrm{M}$ forward and reverse primers in a total volume of 25 $\mu l$. The cycling conditions were: $10 \mathrm{~min}$ at $95^{\circ} \mathrm{C}$, followed by 40 cycles of $95^{\circ} \mathrm{C}$ for $15 \mathrm{~s}$ and $60^{\circ} \mathrm{C}$ for $1 \mathrm{~min}$. Melting curve analysis was performed to identify nonspecific PCR products and primer dimers.

Primers were designed using Primer Express ${ }^{\circledR}$ Software for Real-Time PCR 3.0 (Applied Biosystems). Microarray data were validated by analyzing the expression profile at 0,2 and $24 \mathrm{~h}$ excess light stress. The fold change between treated and untreated samples was compared to the transcriptomic data, and a linear correlation coefficient was calculated for each gene. The detailed GRT-PCR results for eight genes are shown in Additional file 2: Figure S2. Among 20 genes, 16 showed good correlation between qRT-PCR and microarray data $\left(\mathrm{R}^{2}>0.9\right)$.

\section{ROS measurements}

Steady-state accumulation of ROS in leaves was quantified using specific fluorogenic probes: singlet oxygen sensor green (SOSG), dichlorofluorescein (DCF) and proxylfluorescammine (proxf) (Molecular Probe, Eugene). SOSG is highly selective for ${ }^{1} \mathrm{O}_{2}$, whose presence increases its $530 \mathrm{~nm}$ emission band [118]. DCF reacts with hydrogen peroxide $\left(\mathrm{H}_{2} \mathrm{O}_{2}\right)$ and hydroxyl radicals $(\mathrm{OH} \cdot)$ whereas proxF is selective for superoxide anions $\left(\mathrm{O}_{2}{ }^{-}\right)$and hydroxyl radicals, and their emission at 520 and $550 \mathrm{~nm}$, respectively, increases upon exposure (Molecular Probe handbook). 6-weeks-old leaves were detached from plants grown at $120 \mu \mathrm{mol}$ photons $\mathrm{m}^{-2} \mathrm{~s}^{-1}$, $24^{\circ} \mathrm{C}, 8 \mathrm{~h}$ light $/ 16 \mathrm{~h}$ dark, kept at $10^{\circ} \mathrm{C}, 25 \mu \mathrm{mol}$ photons $\mathrm{m}^{-2} \mathrm{~s}^{-1}$ for 48 hours. Leaves were infiltrated with the dye solution (SOSG $5 \mu \mathrm{M}$, DCF $1 \mathrm{mM}$ and proxF $1 \mathrm{mM}$ ) and illuminated with strong red light $(\lambda>600 \mathrm{~nm}, 1600 \mu \mathrm{mol}$ $\left.\mathrm{m}^{-2} \mathrm{~s}^{-1}\right)$ at $10^{\circ} \mathrm{C}$. We looked for increases in ROS-specific fluorescence to quantify ROS levels: SOSG $\left(\lambda_{\text {exc }} 480 \mathrm{~nm}\right.$, $\lambda_{\text {emis }} 530 \mathrm{~nm}$ ); DCF $\left(\lambda_{\text {exc }} 490 \mathrm{~nm}, \lambda_{\text {emis }} 525 \mathrm{~nm}\right)$; proxF $\left(\lambda_{\text {exc }} 420 \mathrm{~nm}, \lambda_{\text {emis }} 515 \mathrm{~nm}\right)$.

\section{Extraction and measurements of metabolites}

WT and npq1lut2 rosettes were pre-treated for $48 \mathrm{hrs}$ at $10^{\circ} \mathrm{C}$ as above described, then were exposed to photoxidative conditions $\left(1000 \mu \mathrm{mol}\right.$ photon $\mathrm{m}^{-2} \mathrm{~s}^{-1}, 10^{\circ} \mathrm{C}, 16 \mathrm{~h}$ light $/ 8 \mathrm{~h}$ dark). Leaves were harvested and immediately frozen in liquid nitrogen at the same time of the day over a 6-day stress period. Plant material was ground to a fine powder in liquid nitrogen and either used immediately for assays or stored at $-80^{\circ} \mathrm{C}$. Ascorbate and glutathione were extracted and assayed following the method developed by Queval and Noctor [119]. ATP and ADP were assayed as previously described [120]. Amino acids and sugars were extracted and quantified as described by [121].

\section{In vivo fluorescence and NPQ measurements}

Non-photochemical quenching of chlorophyll fluorescence (NPQ), maximum quantum efficiency of PSII (Fv/ $\mathrm{Fm})$ and photochemical quenching $(\mathrm{qP})$ were measured with a PAM 101 fluorimeter (Walz, Effeltich, Germany) and were calculated according to [122]. Measurements were registered at the same hour every day over a 6day-long stress treatment above described. For in vivo fluorescence measurements, leaves were illuminated for $25 \mathrm{~min}\left(1000 \mu \mathrm{mol}\right.$ photon $\left.\mathrm{m}^{-2} \mathrm{~s}^{-1}, 10^{\circ} \mathrm{C}\right)$ and photosynthetic parameters were determined during steady-state photosynthesis.

\section{Pigment analysis}

Pigments were extracted from whole leaves with $80 \%$ acetone $(\mathrm{v} / \mathrm{v})$, then separated and quantified by HPLC [10].

\section{Membrane isolation and thylakoid protein separation}

Unstacked thylakoids were isolated from dark-adapted leaves or leaves treated with intense light as previously described [123]. SDS-PAGE analysis was performed with the Tris-Tricine buffer system [124]. Non-denaturing Deriphat-PAGE was performed following the method developed by Peter and Thornber $[125,126]$. For the identification of oxidized proteins, polypeptides were transferred to nitrocellulose membrane and carbonylated 
residues were identified by western blotting using the OxyBlot kit (Millipore). For immunoblot titration of CP47 (PsbC, PSII inner antennae), LHCII (Lhcb1, PSII outer antennae) and PsaA (PSI core complex), thylakoids corresponding to $0.5,1,2$ and $4 \mu \mathrm{g}$ of chlorophylls were separated by SDS-PAGE and the proteins detected by western blot with specific antibodies as described previously [20].

\section{Additional material}

Additional file 1: Tables describing WT and npq1/ut2 transcriptome

Additional file 2: Figures describing WT and npq1/ut2 plant photosynthetic characterization, transcriptome analysis and transcriptome validation.

\section{Acknowledgements}

We thank Dr. Shizue Matsubara (Forschungszentrum Jülich, Germany) for critical reading of the manuscript and helpful discussion and Dr. Simone Zorzan for his help in the comparative analysis shown in Table 6. This work was supported by the Italian Ministry of Research [FIRB PARALLELOMICS RBIP06CTBR to AI.AI. and R.B., PRIN 20073YHRLE_003 to L.D.].

\section{Author details}

${ }^{1}$ Dipartimento di Biotecnologie, Università di Verona, Strada Le Grazie 15, I - 37134 Verona, Italy. ${ }^{2}$ CRA Centro di Ricerca per la Genomica, Via San Protaso 302, 29017 Fiorenzuola d'Arda, Italy. ${ }^{3}$ Dipartimento di Scienze della Vita, Seconda Università degli Studi di Napoli, Via Vivaldi 43, Caserta, Italy. ${ }^{4}$ Dipartimento di Scienze Biomediche, Università di Modena e Reggio Emilia, Via Campi 287, 41100 Modena, Italy.

\section{Authors' contributions}

AA carried out the molecular genetic studies and drafted the manuscript; LD carried out the biochemical and photosynthetic characterization of plants under photoxidative conditions, measurements of ROS and drafted the manuscript; PC carried out metabolomic analysis; AA. and ER participated in the RNA isolation, microarray experiments and statistical analysis of data, quantitative real-time PCR; LC and RB conceived the study and participated in its design and coordination. All authors read and approved the final manuscript.

\section{Received: 28 January 2011 Accepted: 11 April 2011}

Published: 11 April 2011

\section{References}

1. Barber J, Andersson B: Too Much of A Good Thing - Light Can be Bad for Photosynthesis. Trends in Biochemical Sciences 1992, 17:61-66.

2. Scheible WR, GonzalezFontes A, Morcuende R, Lauerer M, Geiger M, Glaab J, Gojon A, Schulze ED, Stitt M: Tobacco mutants with a decreased number of functional nia genes compensate by modifying the diurnal regulation of transcription, post-translational modification and turnover of nitrate reductase. Planta 1997, 203:304-319.

3. Desnos T: Root branching responses to phosphate and nitrate. Current Opinion in Plant Biology 2008, 11:82-87.

4. Munns R: Comparative physiology of salt and water stress. Plant Cell and Environment 2002, 25:239-250.

5. Gilmour SJ, Zarka DG, Stockinger EJ, Salazar MP, Houghton JM, Thomashow MF: Low temperature regulation of the Arabidopsis CBF family of AP2 transcriptional activators as an early step in cold-induced COR gene expression. Plant Journal 1998, 16:433-442.

6. Lee JH, Hubel A, Schoffl F: Derepression of the Activity of GeneticallyEngineered Heat-Shock Factor Causes Constitutive Synthesis of HeatShock Proteins and Increased Thermotolerance in Transgenic Arabidopsis. Plant Journal 1995, 8:603-612.
7. Lillo C, Lea US, Ruoff P: Nutrient depletion as a key factor for manipulating gene expression and product formation in different branches of the flavonoid pathway. Plant Cell and Environment 2008, 31:587-601.

8. Lepiniec L, Debeaujon I, Routaboul JM, Baudry A, Pourcel L, Nesi N, Caboche M: Genetics and biochemistry of seed flavonoids. Annual Review of Plant Biology 2006, 57:405-430.

9. DellaPenna D, Pogson BJ: Vitamin synthesis in plants: Tocopherols and carotenoids. Annual Review of Plant Biology 2006, 57:711-738.

10. Havaux M, Eymery F, Porfirova S, Rey P, Dormann P: Vitamin E protects against photoinhibition and photooxidative stress in Arabidopsis thaliana. Plant Cell 2005, 17:3451-3469.

11. Dal Bosco C, Busconi M, Govoni C, Baldi P, Stanca AM, Crosatti C, Bassi R, Cattivelli L: cor Gene expression in barley mutants affected in chloroplast development and photosynthetic electron transport. Plant Physiol 2003, 131:793-802

12. Fernandez AP, Strand A: Retrograde signaling and plant stress: plastid signals initiate cellular stress responses. Current Opinion in Plant Biology 2008, 11:509-513.

13. Svensson JT, Crosatti C, Campoli C, Bassi R, Stanca AM, Close TJ, Cattivelli L: Transcriptome analysis of cold acclimation in barley Albina and Xantha mutants. Plant Physiol 2006, 141:257-270.

14. Bassi R, Caffarri S: Lhc proteins and the regulation of photosynthetic light harvesting function by xanthophylls. Photosynthesis Research 2000, 64:243-256.

15. de Bianchi S, Ballottari M, Dall'Osto L, Bassi R: Regulation of plant light harvesting by thermal dissipation of excess energy. Biochem Soc Trans 2010, 38:651-660.

16. Horton P, Johnson MP, Perez-Bueno ML, Kiss AZ, Ruban AV: Photosynthetic acclimation: Does the dynamic structure and macro-organisation of photosystem II in higher plant grana membranes regulate light harvesting states? Febs Journal 2008, 275:1069-1079.

17. Betterle N, Ballottari M, Zorzan S, de Bianchi S, Cazzaniga S, Dall'Osto L, Morosinotto T, Bassi R: Light-induced Dissociation of an Antenna Heterooligomer Is Needed for Non-photochemical Quenching Induction. J Biol Chem 2009, 284:15255-15266.

18. Miloslavina Y, Grouneva I, Lambrev PH, Lepetit B, Goss R, Wilhelm C, Holzwarth AR: Ultrafast fluorescence study on the location and mechanism of non-photochemical quenching in diatoms. Biochimica et Biophysica Acta-Bioenergetics 2009, 1787:1189-1197.

19. Anderson JM, Chow WS, Park YI: The grand design of photosynthesis: Acclimation of the photosynthetic apparatus to environmental cues. Photosynthesis Research 1995, 46:129-139.

20. Ballottari M, Dall'Osto L, Morosinotto T, Bassi R: Contrasting behavior of higher plant photosystem I and II antenna systems during acclimation. J Biol Chem 2007, 282:8947-8958.

21. Keegstra K, Cline K: Protein import and routing systems of chloroplasts. Plant Cell 1999, 11:557-570.

22. Leister D: Chloroplast research in the genomic age. Trends in Genetics 2003, 19:47-56.

23. Anderson LE, Levin DA: Chloroplast aldolase is controlled by a nuclear gene. Plant Physiol 1970, 46:819-820.

24. Batschauer A, Mosinger E, Kreuz K, Dorr I, Apel K: The implication of a plastid-derived factor in the transcriptional control of nuclear genes encoding the light-harvesting chlorophyll a/b protein. Eur J Biochem 1986, 154:625-634

25. Nott A, Jung HS, Koussevitzky S, Chory J: PLASTID-TO-NUCLEUS RETROGRADE SIGNALING. Annual Review of Plant Biology 2006, 57:739-759.

26. Woodson JD, Chory J: Coordination of gene expression between organellar and nuclear genomes. Nature Reviews Genetics 2008, 9:383-395

27. Kleine $T$, Voigt $C$, Leister D: Plastid signalling to the nucleus: messengers still lost in the mists? Trends in Genetics 2009, 25:185-190.

28. Vanderauwera S, Zimmermann $P$, Rombauts $S$, Vandenabeele $S$, Langebartels C, Gruissem W, Inze D, Van Breusegem F: Genome-wide analysis of hydrogen peroxide-regulated gene expression in Arabidopsis reveals a high light-induced transcriptional cluster involved in anthocyanin biosynthesis. Plant Physiol 2005, 139:806-821.

29. op den Camp RGL, Przybyla D, Ochsenbein C, Laloi C, Kim CH, Danon A Wagner D, Hideg E, Gobel C, Feussner I, et al: Rapid induction of distinct stress responses after the release of singlet oxygen in arabidopsis. Plant Cell 2003, 15:2320-2332. 
30. Laloi C, Stachowiak M, Pers-Kamczyc E, Warzych E, Murgia I, Apel K: Crosstalk between singlet oxygen- and hydrogen peroxide-dependent signaling of stress responses in Arabidopsis thaliana. Proceedings of the National Academy of Sciences of the United States of America 2007, 104:672-677.

31. Strand A, Asami T, Alonso J, Ecker JR, Chory J: Chloroplast to nucleus communication triggered by accumulation of Mg-protoporphyrinIX Nature 2003, 421:79-83.

32. Pfannschmidt T, Nilsson A, Allen JF: Photosynthetic control of chloroplast gene expression. Nature 1999, 397:625-628.

33. Moulin M, McCormac AC, Terry MJ, Smith AG: Tetrapyrrole profiling in Arabidopsis seedlings reveals that retrograde plastid nuclear signaling is not due to Mg-protoporphyrin IX accumulation. Proc Natl Acad Sci USA 2008, 105:15178-15183.

34. Fey $V$, Wagner R, Brautigam $K$, Wirtzt M, Hell R, Dietzmann A, Leister D, Oelmuller R, Pfannschmidt T: Retrograde plastid redox signals in the expression of nuclear genes for chloroplast proteins of Arabidopsis thaliana. J Biol Chem 2005, 280:5318-5328.

35. Frigerio S, Campoli C, Zorzan S, Fantoni LI, Crosatti C, Drepper F, Haehnel W, Cattivelli L, Morosinotto T, Bassi R: Photosynthetic antenna size in higher plants is controlled by the plastoquinone redox state at the post-transcriptional rather than transcriptional level. J Biol Chem 2007, 282:29457-29469.

36. Gadjev I, Vanderauwera S, Gechev TS, Laloi C, Minkov IN, Shulaev V, Apel K, Inze D, Mittler R, Van Breusegem F: Transcriptomic footprints disclose specificity of reactive oxygen species signaling in Arabidopsis. Plant Physiol 2006, 141:436-445.

37. Miller G, Shulaev V, Mittler R: Reactive oxygen signaling and abiotic stress. Physiol Plant 2008, 133:481-489.

38. Van Breusegem F, Bailey-Serres J, Mittler R: Unraveling the tapestry of networks involving reactive oxygen species in plants. Plant Physio/ 2008 147:978-984.

39. Apel K, Hirt H: Reactive oxygen species: Metabolism, oxidative stress, and signal transduction. Annual Review of Plant Biology 2004, 55:373-399.

40. Delledonne M, Xia YJ, Dixon RA, Lamb C: Nitric oxide functions as a signal in plant disease resistance. Nature 1998, 394:585-588.

41. Kwak JM, Mori IC, Pei ZM, Leonhardt N, Torres MA, Dangl JL, Bloom RE,

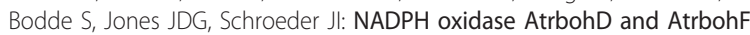
genes function in ROS-dependent ABA signaling in Arabidopsis. Embo Journal 2003, 22:2623-2633.

42. Mclnnis SM, Desikan R, Hancock JT, Hiscock SJ: Production of reactive oxygen species and reactive nitrogen species by angiosperm stigmas and pollen: potential signalling crosstalk? New Phytologist 2006, 172:221-228

43. Potocky M, Jones MA, Bezvoda R, Smirnoff N, Zarsky V: Reactive oxygen species produced by NADPH oxidase are involved in pollen tube growth. New Phytologist 2007, 174:742-751.

44. Foyer $\mathrm{CH}$, Noctor $\mathrm{G}$ : Redox regulation in photosynthetic organisms: signaling, acclimation, and practical implications. Antioxid Redox Signal 2009, 11:861-905.

45. Mullineaux PM, Rausch T: Glutathione, photosynthesis and the redox regulation of stress-responsive gene expression. Photosynth Res 2005, 86:459-474.

46. Triantaphylides C, Havaux M: Singlet oxygen in plants: production, detoxification and signaling. Trends in Plant Science 2009, 14:219-228.

47. Dall'Osto L, Lico C, Alric J, Giuliano G, Havaux M, Bassi R: Lutein is needed for efficient chlorophyll triplet quenching in the major LHCII antenna complex of higher plants and effective photoprotection in vivo under strong light. Bmc Plant Biology 2006, 6.

48. Dall'Osto L, Cazzaniga S, Havaux M, Bassi R: Enhanced Photoprotection by Protein-Bound vs Free Xanthophyll Pools: A Comparative Analysis of Chlorophyll b and Xanthophyll Biosynthesis Mutants. Molecular Plant 2010, 3:576-593.

49. Niyogi KK, Shih C, Chow WS, Pogson BJ, DellaPenna D, Bjorkman O: Photoprotection in a zeaxanthin- and lutein-deficient double mutant of Arabidopsis. Photosynthesis Research 2001, 67:139-145.

50. Meskauskiene R, Nater M, Goslings D, Kessler F, den Camp RO, Apel K: FLU: A negative regulator of chlorophyll biosynthesis in Arabidopsis thaliana. Proceedings of the National Academy of Sciences of the United States of America 2001, 98:12826-12831.
51. Wagner D, Przybyla D, Camp ROD, Kim C, Landgraf F, Lee KP, Wursch M, Laloi C, Nater M, Hideg $E$, et al: The genetic basis of singlet oxygeninduced stress responses of Arabidopsis thaliana. Science 2004, 306:1183-1185

52. Triantaphylides C, Krischke M, Hoeberichts FA, Ksas B, Gresser G, Havaux M Van Breusegem F, Mueller MJ: Singlet oxygen is the major reactive oxygen species involved in photooxidative damage to plants. Plant Physiol 2008, 148:960-968.

53. Lee KP, Kim C, Landgraf F, Apel K: EXECUTER1- and EXECUTER2dependent transfer of stress-related signals from the plastid to the nucleus of Arabidopsis thaliana. Proceedings of the National Academy of Sciences of the United States of America 2007, 104:10270-10275.

54. Ruepp A, Zollner A, Maier D, Albermann K, Hani J, Mokrejs M, Tetko I, Guldener U, Mannhaupt G, Munsterkotter M, et al: The FunCat, a functional annotation scheme for systematic classification of proteins from whole genomes. Nucleic Acids Research 2004, 32:5539-5545.

55. OToole N, Hattori M, Andres C, lida K, Lurin C, Schmitz-Linneweber C, Sugita $M$, Small I: On the expansion of the pentatricopeptide repeat gene family in plants. Mol Biol Evol 2008, 25:1120-1128.

56. Mano J, Torii Y, Takimoto K, Inze D, Asada K: Novel enzyme 2-alkenal alpha,beta-hydrogenase has an antioxidant function in vivo. Plant and Cell Physiology 2003, 44:S26.

57. Rouhier N, Vieira Dos SC, Tarrago L, Rey P: Plant methionine sulfoxide reductase $A$ and B multigenic families. Photosynth Res 2006, 89:247-262.

58. Zhu JH, Fu XM, Koo YD, Zhu JK, Jenney FE, Adams MWW, Zhu YM, Shi HZ, Yun DJ, Hasegawa PM, et al: An enhancer mutant of Arabidopsis salt overly sensitive 3 mediates both ion homeostasis and the oxidative stress response. Molecular and Cellular Biology 2007, 27:5214-5224.

59. Pose D, Castanedo I, Borsani O, Nieto B, Rosado A, Taconnat L, Ferrer A, Dolan L, Valpuesta V, Botella MA: Identification of the Arabidopsis dry2/ sqe1-5 mutant reveals a central role for sterols in drought tolerance and regulation of reactive oxygen species. Plant J 2009, 59:63-76.

60. Rasbery JM, Shan H, LeClair RJ, Norman M, Matsuda SP, Bartel B: Arabidopsis thaliana squalene epoxidase 1 is essential for root and seed development. J Biol Chem 2007, 282:17002-17013.

61. Invitrogen Molecular Probes: The Handbook: A Guide to Fluorescent Probes and Labeling Technologies 2009.

62. Maisch T, Baier J, Franz B, Maier M, Landthaler M, Szeimies RM, Baumler W: The role of singlet oxygen and oxygen concentration in photodynamic inactivation of bacteria. Proceedings of the National Academy of Sciences of the United States of America 2007, 104:7223-7228.

63. Flors C, Fryer MJ, Waring J, Reeder B, Bechtold U, Mullineaux PM, Nonell S, Wilson MT, Baker NR: Imaging the production of singlet oxygen in vivo using a new fluorescent sensor, Singlet Oxygen Sensor Green (R). Journal of Experimental Botany 2006, 57:1725-1734.

64. Ramel F, Sulmon C, Bogard M, Couee I, Gouesbet G: Differential patterns of reactive oxygen species and antioxidative mechanisms during atrazine injury and sucrose-induced tolerance in Arabidopsis thaliana plantlets. Bmc Plant Biology 2009, 9.

65. Mozzo M, Dall'Osto L, Hienerwadel R, Bassi R, Croce R: Photoprotection in the antenna complexes of photosystem II - Role of individual xanthophylls in chlorophyll triplet quenching. J Biol Chem 2008, 283:6184-6192

66. Piippo M, Allahverdiyeva Y, Paakkarinen V, Suoranta UM, Battchikova N, Aro EM: Chloroplast-mediated regulation of nuclear genes in Arabidopsis thaliana in the absence of light stress. Physiological Genomics 2006, 25:142-152.

67. Walters RG: Towards an understanding of photosynthetic acclimation. Journal of Experimental Botany 2005, 56:435-447.

68. Krieger-Liszkay A: Singlet oxygen production in photosynthesis. Journal of Experimental Botany 2005, 56:337-346.

69. Klimmek F, Sjodin A, Noutsos C, Leister D, Jansson S: Abundantly and rarely expressed Lhc protein genes exhibit distinct regulation patterns in plants. Plant Physiol 2006, 140:793-804.

70. Heddad M, Noren H, Reiser V, Dunaeva M, Andersson B, Adamska I: Differential expression and localization of early light-induced proteins in Arabidopsis. Plant Physiol 2006, 142:75-87.

71. McKim SM, Durnford DG: Translational regulation of light-harvesting complex expression during photoacclimation to high-light in Chlamydomonas reinhardtii. Plant Physiol Biochem 2006, 44:857-865. 
72. Petracek ME, Dickey LF, Huber SC, Thompson WF: Light-regulated changes in abundance and polyribosome association of ferredoxin mRNA are dependent on photosynthesis. Plant Cell 1997, 9:2291-2300.

73. Aluru MR, Zola J, Foudree A, Rodermel SR: Chloroplast photooxidationinduced transcriptome reprogramming in Arabidopsis immutans white leaf sectors. Plant Physiol 2009, 150:904-923.

74. Campoli C, Caffarri S, Svensson JT, Bassi R, Stanca AM, Cattivelli L, Crosatti C Parallel pigment and transcriptomic analysis of four barley Albina and Xantha mutants reveals the complex network of the chloroplastdependent metabolism. Plant Molecular Biology 2009, 71:173-191.

75. Lokstein H, Tian L, Polle JEW, DellaPenna D: Xanthophyll biosynthetic mutants of Arabidopsis thaliana: altered nonphotochemical quenching of chlorophyll fluorescence is due to changes in Photosystem II antenna size and stability. Biochimica et Biophysica Acta-Bioenergetics 2002, 1553:309-319.

76. Pogson BJ, Niyogi KK, Bjorkman O, DellaPenna D: Altered xanthophyll compositions adversely affect chlorophyll accumulation and nonphotochemical quenching in Arabidopsis mutants. Proceedings of the National Academy of Sciences of the United States of America 1998, 95:13324-13329.

77. Havaux M, Dall'Osto L, Bassi R: Zeaxanthin has enhanced antioxidant capacity with respect to all other xanthophylls in Arabidopsis leaves and functions independent of binding to PSII antennae(1[C][W]). Plant Physiol 2007, 145:1506-1520

78. Niyogi KK: Photoprotection revisited: Genetic and molecular approaches. Annual Review of Plant Physiology and Plant Molecular Biology 1999, 50:333-359.

79. Rinalducci S, Pedersen JZ, Zolla L: Formation of radicals from singlet oxygen produced during photoinhibition of isolated light-harvesting proteins of photosystem II. Biochimica et Biophysica Acta-Bioenergetics 2004, 1608:63-73.

80. Ledford HK, Baroli I, Shin JW, Fischer BB, Eggen RI, Niyogi KK: Comparative profiling of lipid-soluble antioxidants and transcripts reveals two phases of photo-oxidative stress in a xanthophyll-deficient mutant of Chlamydomonas reinhardtii. Mol Genet Genomics 2004, 272:470-479.

81. Fischer BB, Krieger-Liszkay A, Hideg E, Snyrychova I, Wiesendanger M, Eggen RI: Role of singlet oxygen in chloroplast to nucleus retrograde signaling in Chlamydomonas reinhardtii. FEBS Lett 2007, 581:5555-5560.

82. Kim C, Meskauskiene R, Apel K, Laloi C: No single way to understand singlet oxygen signalling in plants. EMBO Rep 2008, 9:435-439.

83. Cazzonelli Cl, Pogson BJ: Source to sink: regulation of carotenoid biosynthesis in plants. Trends Plant Sci 2010.

84. Biehl A, Richly E, Noutsos C, Salamini F, Leister D: Analysis of 101 nuclear transcriptomes reveals 23 distinct regulons and their relationship to metabolism, chromosomal gene distribution and co-ordination of nuclear and plastid gene expression. Gene 2005, 344:33-41.

85. Khandelwal A, Elvitigala T, Ghosh B, Quatrano RS: Arabidopsis Transcriptome Reveals Control Circuits Regulating Redox Homeostasis and the Role of an AP2 Transcription Factor. Plant Physiol 2008, 148:2050-2058.

86. Lee KP, Kim C, Lee DW, Apel K: TIGRINA d, required for regulating the biosynthesis of tetrapyrroles in barley, is an ortholog of the FLU gene of Arabidopsis thaliana. Febs Letters 2003, 553:119-124.

87. Shao N, Krieger-Liszkay A, Schroda M, Beck CF: A reporter system for the individual detection of hydrogen peroxide and singlet oxygen: its use for the assay of reactive oxygen species produced in vivo. Plant Journal 2007, 50:475-487.

88. de Torres M, Sanchez P, Fernandez-Delmond I, Grant M: Expression profiling of the host response to bacterial infection: the transition from basal to induced defence responses in RPM1-mediated resistance. Plant J 2003, 33:665-676

89. Havaux M, Kloppstech K: The protective functions of carotenoid and flavonoid pigments against excess visible radiation at chilling temperature investigated in Arabidopsis npq and tt mutants. Planta 2001, 213:953-966.

90. Dall'Osto L, Fiore A, Cazzaniga S, Giuliano G, Bassi R: Different roles of alpha- and beta-branch xanthophylls in photosystem assembly and photoprotection. J Biol Chem 2007, 282:35056-35068.

91. Dall'Osto L, Cazzaniga S, North H, Marion-Poll A, Bassi R: The Arabidopsis aba4-1 Mutant Reveals a Specific Function for Neoxanthin in Protection against Photooxidative Stress. Plant Cell 2007, 19:1048-1064.
92. Demmig-Adams B, Adams WW, Heber U, Neimanis S, Winter K, Kruger A, Czygan FC, Bilger W, Bjorkman O: Inhibition of Zeaxanthin Formation and of Rapid Changes in Radiationless Energy Dissipation by Dithiothreitol in Spinach Leaves and Chloroplasts. Plant Physiol 1990, 92:293-301.

93. Bailey S, Walters RG, Jansson S, Horton P: Acclimation of Arabidopsis thaliana to the light environment: the existence of separate low light and high light responses. Planta 2001, 213:794-801.

94. Golan T, Muller-Moule P, Niyogi KK: Photoprotection mutants of Arabidopsis thaliana acclimate to high light by increasing photosynthesis and specific antioxidants. Plant Cell Environ 2006, 29:879-887.

95. Havaux M, Niyogi KK: The violaxanthin cycle protects plants from photooxidative damage by more than one mechanism. Proc Natl Acad Sci USA 1999, 96:8762-8767.

96. Tanaka R, Tanaka A: Tetrapyrrole biosynthesis in higher plants. Annu Rev Plant Biol 2007, 58:321-346.

97. Beale SI: Enzymes of chlorophyll biosynthesis. Photosynthesis Research 1999, 60:43-73.

98. Goslings D, Meskauskiene R, Kim CH, Lee KP, Nater M, Apel K: Concurrent interactions of heme and FLU with Glu tRNA reductase (HEMA1), the target of metabolic feedback inhibition of tetrapyrrole biosynthesis, in dark- and light-grown Arabidopsis plants. Plant Journal 2004, 40:957-967.

99. Pursiheimo S, Mulo P, Rintamaki E, Aro EM: Coregulation of lightharvesting complex II phosphorylation and Ihcb mRNA accumulation in winter rye. Plant Journal 2001, 26:317-327.

100. Li XP, Bjorkman O, Shih C, Grossman AR, Rosenquist M, Jansson S, Niyogi KK: A pigment-binding protein essential for regulation of photosynthetic light harvesting. Nature 2000, 403:391-395.

101. Tzvetkova-Chevolleau T, Franck F, Alawady AE, Dall'Osto L, Carriere F, Bassi R, Grimm B, Nussaume L, Havaux M: The light stress-induced protein ELIP2 is a regulator of chlorophyll synthesis in Arabidopsis thaliana. Plant J 2007, 50:795-809.

102. Jansson S: A guide to the Lhc genes and their relatives in Arabidopsis. Trends in Plant Science 1999, 4:236-240.

103. Caffarri S, Frigerio S, Olivieri E, Righetti PG, Bassi R: Differential accumulation of Lhcb gene products in thylakoid membranes of Zea mays plants grown under contrasting light and temperature conditions. Proteomics 2005, 5:758-768

104. Delatorre WR, Burkey KO: Acclimation of Barley to Changes in LightIntensity - Photosynthetic Electron-Transport Activity and Components. Photosynthesis Research 1990, 24:127-136.

105. Das KC, Das CK: Thioredoxin, a singlet oxygen quencher and hydroxyl radical scavenger: redox independent functions. Biochem Biophys Res Commun 2000, 277:443-447.

106. Laloi C, Mestres-Ortega D, Marco Y, Meyer Y, Reichheld JP: The Arabidopsis cytosolic thioredoxin h5 gene induction by oxidative stress and its $\mathrm{W}$ box-mediated response to pathogen elicitor. Plant Physiol 2004, 134:1006-1016.

107. Sun CW, Huang YC, Chang HY: CIA2 Coordinately Up-Regulates Protein Import and Synthesis in Leaf Chloroplasts. Plant Physiol 2009, 150:879-888

108. Alonso JM, Stepanova AN, Leisse TJ, Kim CJ, Chen HM, Shinn P, Stevenson DK, Zimmerman J, Barajas P, Cheuk R, et al: Genome-wide Insertional mutagenesis of Arabidopsis thaliana. Science 2003, 301:653-657.

109. Coic $Y$, Lesaint C: [Determination of the accumulation of nitrates in plant tissues]. Ann Nutr Aliment 1980, 34:929-936.

110. Kreps JA, Simon AE: Environmental and genetic effects on circadian clock-regulated gene expression in Arabidopsis. Plant Cell 1997, 9:297-304.

111. Irizarry RA, Hobbs B, Collin F, Beazer-Barclay YD, Antonellis KJ, Scherf U, Speed TP: Exploration, normalization, and summaries of high density oligonucleotide array probe level data. Biostatistics 2003, 4:249-264.

112. Gautier L, Cope L, Bolstad BM, Irizarry RA: affy-analysis of Affymetrix GeneChip data at the probe level. Bioinformatics 2004, 20:307-315.

113. Benjamini Y, Drai D, Elmer G, Kafkafi N, Golani I: Controlling the false discovery rate in behavior genetics research. Behav Brain Res 2001, 125:279-284.

114. Chen JJ, Wang SJ, Tsai CA, Lin CJ: Selection of differentially expressed genes in microarray data analysis. Pharmacogenomics J 2007, 7:212-220. 
115. Soukas A, Cohen P, Socci ND, Friedman JM: Leptin-specific patterns of gene expression in white adipose tissue. Genes \& Development 2000, 14:963-980.

116. Heyer $L$, Kruglyak S, Yooseph S: Exploring expression data: Identification and analysis of coexpressed genes. Genome Research 1999, 9:1106-1115.

117. Parkinson H, Kapushesky M, Shojatalab M, Abeygunawardena N, Coulson R, Farne A, Holloway E, Kolesnykov N, Lilja P, Lukk M, et al: ArrayExpress - a public database of microarray experiments and gene expression profiles. Nucleic Acids Research 2007, 35:D747-D750.

118. Flors C, Fryer MJ, Waring J, Reeder B, Bechtold U, Mullineaux PM, Nonell S, Wilson MT, Baker NR: Imaging the production of singlet oxygen in vivo using a new fluorescent sensor, Singlet Oxygen Sensor Green. J Exp Bot 2006, 57:1725-1734.

119. Queval G, Noctor G: A plate reader method for the measurement of NAD, NADP, glutathione, and ascorbate in tissue extracts: Application to redox profiling during Arabidopsis rosette development. Anal Biochem 2007, 363:58-69.

120. Gibon Y, Vigeolas H, Tiessen A, Geigenberger P, Stitt M: Sensitive and high throughput metabolite assays for inorganic pyrophosphate, ADPGlc, nucleotide phosphates, and glycolytic intermediates based on a novel enzymic cycling system. Plant J 2002, 30:221-235.

121. Carillo P, Mastrolonardo G, Nacca F, Fuggi A: Nitrate reductase in durum wheat seedlings as affected by nitrate nutrition and salinity. Functional Plant Biology 2005, 32:209-219.

122. Van Kooten O, Snell JHF: The use of chlorophyll fluorescence nomenclature in plant stress physiology. Photosynth Res 1990, 25:147-150.

123. Bassi R, Rigoni F, Barbatto R, Giacometti GM: Light-harvesting chlorophyll a/b proteins (LHCII) populations in phosphorylated membranes. Biochimica et Biophysica Acta (BBA)-Bioenergetics 1988, 936:29-38.

124. Schagger $H$, von Jagow $G$ : Blue native electrophoresis for isolation of membrane protein complexes in enzymatically active form. Anal Biochem 1991, 199:223-231.

125. Peter GF, Thornber JP: Biochemical-Composition and Organization of Higher-Plant Photosystem-li Light-Harvesting Pigment-Proteins. J Biol Chem 1991, 266:16745-16754.

126. Garcion C, Baltensperger R, Fournier T, Pasquier J, Schnetzer MA, Gabriel JP, Metraux JP: FiRe and microarrays: a fast answer to burning questions. Trends Plant Sci 2006, 11:320-322.

doi:10.1186/1471-2229-11-62

Cite this article as: Alboresi et al:: Reactive oxygen species and

transcript analysis upon excess light treatment in wild-type Arabidopsis thaliana vs a photosensitive mutant lacking zeaxanthin and lutein. BMC Plant Biology 2011 11:62.

\section{Submit your next manuscript to BioMed Central and take full advantage of:}

- Convenient online submission

- Thorough peer review

- No space constraints or color figure charges

- Immediate publication on acceptance

- Inclusion in PubMed, CAS, Scopus and Google Scholar

- Research which is freely available for redistribution

Submit your manuscript at www.biomedcentral.com/submit 